\title{
The old and the new plankton: ecological replacement of associations of mollusc plankton and giant filter feeders after the Cretaceous?
}

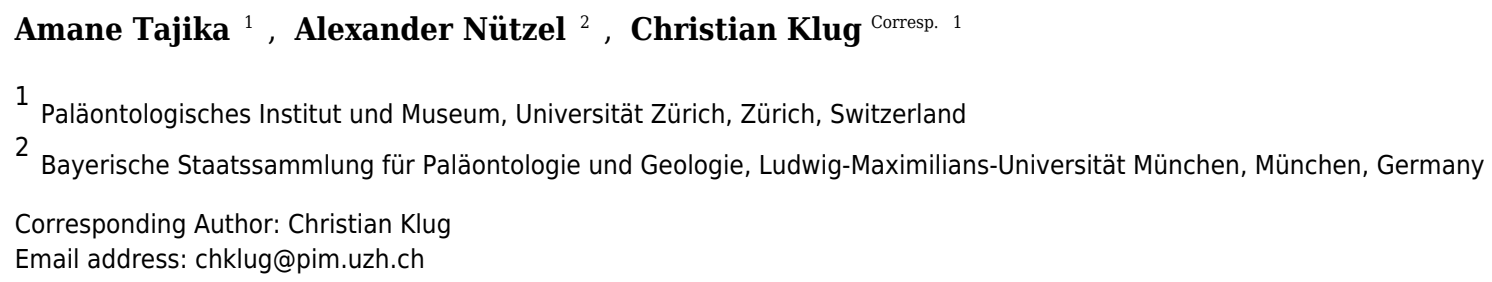

Owing to their great diversity and abundance, ammonites and belemnites represented key elements in Mesozoic food webs. Because of their extreme ontogenetic size increase by up to three orders of magnitude, their position in the food webs likely changed during ontogeny. Here, we reconstruct the number of eggs laid by large adult females of these cephalopods and discuss developmental shifts in their ecologic roles. Based on similarities in conch morphology, size, habitat and abundance, we suggest that similar niches occupied in the Cretaceous by juvenile ammonites and belemnites were vacated during the extinction and later partially filled by holoplanktonic gastropods. As primary consumers, these extinct cephalopod groups were important constituents of the plankton and a principal food source for planktivorous organisms. As victims or, respectively, profiteers of this case of ecological replacement, filter feeding chondrichthyans and cetaceans likely filled the niches formerly occupied by large pachycormid fishes during the Jurassic and Cretaceous. 
1 The old and the new plankton: ecological replacement of

2 associations of mollusc plankton and giant filter feeders after

\section{3 the Cretaceous?}

4

5 Amane Tajika ${ }^{1}$, Alexander Nützel ${ }^{2}$ and Christian Klug ${ }^{1}$

6 und Geologie, Ludwig-Maximilians-Universität München, München, Germany

Corresponding author Christian Klug, chklug@pim.uzh.ch

\section{ABSTRACT} fishes during the Jurassic and Cretaceous.

${ }^{1}$ Paläontologisches Institut und Museum, Universität Zürich, Zürich, Switzerland. ${ }^{2}$ Bayerische Staatssammlung für Paläontologie

Owing to their great diversity and abundance, ammonites and belemnites represented key elements in Mesozoic food webs. Because of their extreme ontogenetic size increase by up to three orders of magnitude, their position in the food webs likely changed during ontogeny. Here, we reconstruct the number of eggs laid by large adult females of these cephalopods and discuss developmental shifts in their ecologic roles. Based on similarities in conch morphology, size, habitat and abundance, we suggest that similar niches occupied in the Cretaceous by juvenile ammonites and belemnites were vacated during the extinction and later partially filled by holoplanktonic gastropods. As primary consumers, these extinct cephalopod groups were important constituents of the plankton and a principal food source for planktivorous organisms. As victims or, respectively, profiteers of this case of ecological replacement, filter feeding chondrichthyans and cetaceans likely filled the niches formerly occupied by large pachycormid 


\section{INTRODUCTION}

28 The fate of individual groups of marine organisms at mass extinctions is of considerable interest

29 (e.g., Jablonski \& Raup, 1994; Jablonski, 2008). By contrast, the disappearance of entire

30 communities or ecological associations or food webs or important parts of any of these structures

31 from the geologic past still requires a lot of palaeontological research (Hautmann, 2014;

32 Hoffmann et al., 2014; Roopnarine \& Angielczyk 2015). Extinctions of entire communities or

33 ecosystems are most conspicuous during the great mass extinctions (e.g. Foster \& Twitchett,

34 2014), when usually vast new ecospace was freed and thereby, new ecological niches could form

35 during recovery periods.

36 Although it is not the most severe of the Big Five, the end-Cretaceous mass extinction is likely

37 the most famous among those with the greatest severity (McGhee et al., 2013). This fame roots in

38 the facts that popular groups of organisms such as dinosaurs (Sloan et al., 1986; Archibald \&

39 Fastovsky, 2004) and ammonites (Goolaerts, 2010; Kennedy, 1993; Landman et al., 2015) were

40 erased by the consequences of an impact in Mexico and/ or flood basalt-eruptions in India (Keller

41 et al., 2009; Miller et al., 2010; Schulte et al., 2010; Tobin et al., 2012).

42 Marine communities were heavily affected as reflected in a significant reduction of diversity

43 or a partial or even total disappearance of major groups such as ammonoids and belemnites

44 (Doyle, 1992; Marshall \& Ward, 1996; Iba et al., 2011; Olivero, 2012; Landman et al. 2014) as

45 well as planktonic foraminifers (Alvarez et al., 1980; Smit, 1982) and bivalves (Jablonski \&

46 Raup, 1994). Before this extinction, ammonoids were both highly diverse and had evolved a great

47 disparity in the course of the Cretaceous (Ward \& Signor, 1983; Ward, 1996); some of the most

48 bizarre forms (heteromorphs) such as Nipponites, Diplomoceras and Didymoceras appeared,

49 some of which reached impressive sizes (e.g., Diplomoceras, Emericiceras). Furthermore, 
50 members of the family Puzosiidae, which comprises the largest ammonoids of all times, also

51 lived during Cretaceous times (Landois, 1895; Olivero \& Zinsmeister, 1989; Kennedy \& Kaplan,

52 1995). Puzosiids are not only gigantic but they also abundantly occurred worldwide. In addition

53 to this family, members of other ammonite families also reached sizes of around one meter in the

54 Late Cretaceous.

55 The sometimes extreme variation in conch size but also morphological disparity makes it

56 likely that their modes of life and habitats differed as well. This is reflected in hatchling conch

57 morphology, which may produce shapes unknown from adult ammonoid conchs (Klug et al.

58 2016). A further line of reasoning supporting ontogenetic changes in ecology is the change in

59 hydrodynamic properties due to size changes (Jacobs 1992; Jacobs \& Chamberlain 1996; Naglik

60 et al. 2015).

61 The great abundance, wide geographical distribution, extreme diversity, middle to giant size in 62 combination with the likely high fecundity of ammonites raises a number of questions: (i) What

63 respective roles did juvenile and adult ammonites and belemnites play in Cretaceous marine food

64 webs? (ii) The adults were probably planktotrophic consumers, but what was the role of their

65 minute offspring? (iii) What groups filled the ecospace occupied by ammonites, belemnites and

66 their predators after the Cretaceous? (iv) How did this ecological replacement occur?

\section{METHODS}

69 We estimated the fecundity of large Cretaceous ammonites such as Parapuzosia seppenradensis

70 (Fig. 1) using the following facts, assumptions and measurements, which probably applied to all

71 members of the Ammonoidea. (i) We know that the major part of egg-development happened in

72 the body chamber (De Baets et al., 2015; Mironenko \& Rogov, 2015); (ii) there is good evidence

73 that the ammonitella represents the embryonic part of the conch (De Baets et al., 2015); (iii) we

74 suggest that egg-size only slightly exceeded ammonitella-size because of their dense packing in 
75 fossils with embryos preserved in the body chamber (De Baets et al., 2015; Mironenko \& Rogov,

76 2015); and (iv) we followed the proportion of $8 \%$ of the soft body volume being occupied by the

77 gonads according to the proportions known from Recent Nautilus (Tanabe \& Tsukahara, 1987;

78 Korn \& Klug, 2007; De Baets et al., 2015). As far as (iv) is concerned, there is some uncertainty

79 because the proportions of the ovaries are poorly known from ammonoids due to the extremely

80 rare and fragmentary preservation of soft parts (Mironenko \& Rogov, 2015; Lehmann, 1981;

81 Lehmann, 1985; Klug \& Lehmann, 2015; Klug et al., 2012). When regarding the specimens

82 figured by Mironenko \& Rogov (2015), one tends to assume that the gonads filled a much larger

83 portion of the body chamber. This hypothesis finds further support in symmetric bulges in the

84 posterior body chamber in mature Pachydesmoceras (Fig. 1) and scaphitid conchs (Kennedy,

85 1989). These bulges may have offered space for the growing ovaries. Owing to these materials

86 and morphological adult modifications of ammonoid conchs, we calculated alternative maximum

87 egg-numbers using a body chamber volume proportion occupied by gonads of $30 \%$.

88 The largest specimen of the largest ammonite species Parapuzosia seppenradensis is

89 incomplete (Landois, 1895; Kennedy \& Kaplan, 1995). It is an incomplete specimen measuring

$901740 \mathrm{~mm}$ (Fig. 1). We estimated the adult body chamber volume and the surface area of the

91 terminal aperture assuming a body chamber length of about 180 degrees because of shell traces of

92 the missing conch part along the umbilical seam. Accordingly, the maximum diameter dm can be

93 reconstructed to have reached $2200 \mathrm{~mm}$ with a whorl height wh of about $800 \mathrm{~mm}$ and a whorl

94 width ww of about $500 \mathrm{~mm}$. The radiuses would then measure $1250 \mathrm{~mm}\left(\mathrm{r}_{1}\right)$ at the terminal

95 aperture and $950 \mathrm{~mm}\left(\mathrm{r}_{2}\right)$ on the opposite side. Using the wh and ww values, we reconstructed a

96 whorl cross section in CorelDraw and measured the area; accordingly, the cross section area K

97 amounts to almost $320^{\prime} 000 \mathrm{~mm}^{2}$.

98 As shown by De Baets et al. (2012), derived ammonoids (i.e. with fully coiled embryonic

99 conchs) likely had a high fecundity. This is corroborated by the great differences between embryo 
100 size and adult conch size. For example, in the largest specimen of Parapuzosia seppenradense

101 from the Late Cretaceous of Germany, the embryonic conch measured about one millimeter in

102 diameter at hatching, while the adult conch exceeded two meters in diameter (Kennedy \& Kaplan

103 1995; De Baets et al., 2012; De Baets et al., 2015; Korn \& Klug, 2007; Landman et al., 1996;

104 Tanabe et al., 2008). This implies a factor of at least 2000 in diameter increase between embryos

105 and adult macroconchs. Embryonic conch size (ammonitella size) is well documented for most

106 ammonoid clades (De Baets et al., 2015). In Cretaceous ammonoids, ammonitella size ranges

107 between 0.5 and $1.5 \mathrm{~mm}$ with the average being smaller than $1 \mathrm{~mm}$ (De Baets et al., 2015).

108 In order to estimate the absolute gonad volume, we determined the body chamber volume

109 VBC, which can be achieved by applying an equation introduced by Raup \& Chamberlain

110 (1967) and also used by De Baets et al. (2012):

(1) $\mathrm{V}_{\mathrm{BC}}=2 / 3 * \pi *(\mathrm{~K} * \mathrm{Ra} / \ln \mathrm{W}) *\left(1-\mathrm{W}^{-3 \theta / 2 \pi}\right)$

112 with $\mathrm{K}$ - area of the last aperture, $\mathrm{Ra}$ - distance coiling axis to center of mass (estimated $200 \mathrm{~mm}$

113 based on comparisons with species with similar conch shape: Tajika et al. 2015; Naglik et al.,

114 2016), $\theta$ - angular length of the body chamber in radians (equals $\pi$ here, because the body

115 chamber is about $180^{\circ}$ long), the whorl expansion rate for this particular body chamber length

(2) $\mathrm{W}=\left(\mathrm{r}_{1} / \mathrm{r}_{2}\right)^{2 \pi / \theta}$

117 with $r_{1}-$ maximum conch diameter and $r_{2}-$ conch diameter $180^{\circ}$ behind the aperture.

118 In order to compare the embryonic conch size of Cretaceous ammonites to early Thecosomata,

119 we collected data from various publications (for values and references, see Tables 1 to 3). We

120 plotted these values in box plots using Excel.

121 As a further approach to estimate ammmonoid fecundity, we gathered published data on the

122 numbers of eggs per adult female and list those in Table 4 (references of the data sources are

123 given there). Using Excel, we produced a loglog-biplot depicting the relationship between the 
124 estimated number of eggs and the mature conch size in various ammonoids of Devonian to

125 Cretaceous age. Unsurprisingly, there is an exponential relationship between the two parameters.

\section{RESULTS}

\section{Estimating ammonoid fecundity}

129 Applying the data and calculations listed in the method section to the lectotype of Parapuzosia

130 seppenradense, we obtain a whorl expansion rate $\mathrm{W}$ of 1.73 and then an according body chamber

131 volume $\mathrm{V}_{\mathrm{BC}}$ of $137^{\prime} 075^{\prime} 470 \mathrm{~mm}^{3}$. Depending on the proportion of the gonads (between 8 and

$13230 \%$; see discussion in methods), we obtain gonad volumes varying between about 10'000'000

$133 \mathrm{~mm}^{3}$ and 40'000'000 $\mathrm{mm}^{3}$. Assuming an egg-volume of $1 \mathrm{~mm}^{3}$, we obtain numbers of

134 10’000'000 to 40’000'000 eggs per adult female Parapuzosia seppenradensis (see also Fig. 2) if

135 they were semelparous. If we assume iteroparity, these numbers increase by the factor of the

136 number of reproductive cycles. Also, if we assume that the eggs and embryos continued to grow

137 after they were laid (see discussion in Walton et al. 2010), ammonoid fecundity would further

138 increase, but evidence for this is missing in ammonoids (Mironenko \& Rogov, 2015). For an adult

139 female of half the diameter, we would still obtain egg-numbers of between 3'000'000 (8\% gonad

140 volume) and 10’000’000 eggs (30\% gonad volume) at semelparity. Puzosiids and other large

141 Cretaceous ammonoids in the size range between 500 and $1000 \mathrm{~mm}$ are quite common

142 worldwide (e.g. Pachydesmoceras).

143 In Fig. 2, we depict the relationship between the number of eggs per female adult ammonoid

144 using mostly published data and the results presented here. The loglog-biplot shows an

145 exponential relationship between these two parameters, which is not surprising taking into

146 account how the estimates were achieved (De Baets et al., 2012). It also shows some variation

147 scattering around the exponential trend line, which likely roots in the variation of the ratio of

148 embryonic versus adult conch size (e.g., Gyroceratites and Sinzovia have similar adult sizes, but 
149 the embryonic conch is 50\% larger in Gyroceratites; De Baets et al., 2012, 2015, Mironenko \&

150 Rogov, 2015).

151

152 The role of r-strategy in ammonite and belemnite ecology

153 Depending on the proportional gonad size and whether or not ammonites were semelparous or

154 iteroparous, it appears likely that adult females of the largest puzosiid ammonites such as

155 Parapuzosia seppenradensis laid between 10'000'000 and 100'000'000 eggs and ammonoids

156 about half the size still over 1'000'000 eggs. The simple calculation above highlights the

157 likelihood that derived ammonites were extreme r-strategists (respectively fast life strategy),

158 which produced vast amounts of offspring, likely contributing an important part of the plankton

159 in size at the limit from micro- to macroplankton. R-strategy corresponded with high mortality

160 and it is likely that hatchlings and juveniles of ammonites formed a major source of food in the

161 marine realm.

162 As far as belemnites are concerned, their global abundance had already decreased during the

163 Late Cretaceous (prior to the main extinction event), freeing ecospace for, e.g., some other

164 coleoids (Iba et al., 2011). Nevertheless, coleoids with conical phragmocones such as belemnites,

165 diplobelids, Groenlandibelus or Naefia share a small initial chamber and likely small embryonic

166 conchs (Bandel et al., 1984). Above all, there are a lot of similarities between belemnite and

167 ammonite hatchlings such as their small initial chambers, their overall hatchling size, their

168 supposed habitats including the planktonic mode of life and the r-strategy reproductive mode

169 (Ward \& Bandel, 1987; Arkhipkin \& Laptikhovsky, 2012; Doguzhaeva et al. 2014). Accordingly,

170 we assume that belemnite fecundity was also high, although much lower than those of the

171 puzosiid ammonites because of the much lower size difference between adults and embryos

172 (about 100 to 1000 eggs per female).

173 


\section{Which animals ate ammonites?}

175 Evidence for successful and unsuccessful predation on medium to large-sized ammonites is not

176 rare but identifying the actual predator is possible only in very few cases (Keupp, 2012;

177 Hoffmann \& Keupp, 2015). Additionally, most hard parts of ammonites (conch and lower jaw)

178 were likely crushed by the predators and quickly dissolved in the digestive tract, making

179 ammonites as fossilized stomach contents improbable, although a few cases have been reported

180 where juvenile ammonoid remains are preserved in stomachs of Jurassic ammonites (Keupp \&

181 Schweigert 2015; Klug \& Lehmann, 2015). It is even more difficult to find evidence for predators

182 that fed on hatchlings and neanic juveniles of ammonites ( $\mathrm{dm}<10 \mathrm{~mm})$, which must have

183 occurred in vast numbers in the world's oceans of the Mesozoic. These early post-hatching

184 developmental stages probably lived in the water column because their conchs already had

185 functional phragmocones and they are often found in black shales, which were deposited under

186 hypoxic to anoxic bottom water conditions and therefore, a strictly benthic mode of life was

187 impossible (Shigeta, 1993; Nützel \& Mapes, 2001; Mapes \& Nützel, 2009). Thus, pelagic

188 nektonic animals (including older growth stages of ammonites) are the likeliest candidates as

189 predators feeding on these young ammonites: Figure 3 depicts the fitting of juvenile planktonic

190 ammonites and holoplanktonic gastropods with the mesh size of filter feeders of the

191 corresponding time intervals. See Figure 4 for the stratigraphic distribution of the groups

192 discussed here.

193 For abundant and easy prey like juvenile ammonites, a broad range of predators can be

194 hypothesized. Like plankton today, these masses of juvenile ammonites represent perfect food

195 sources for medium-sized to large suspension feeders (invertebrates and vertebrates). From the

196 Cretaceous, giant planktivorous bony fishes (pachycormids: Friedman et al., 2010) have been

197 suggested to be nektonic suspension feeders, which might have fed on plankton comprising a

198 wealth of juvenile ammonites. In the SOM of their paper, Friedman et al. (2010) show a 
199 fragment of the gill rakers; their filaments have a spacing of about $1 \mathrm{~mm}$, which is suitable to

200 filter out hatchlings and juvenile ammonites with conchs of one millimeter in diameter or slightly

201 more (Fig. 3). This trophic relationship is further suggested by the extinction of this group

202 synchronous with the demise of the Ammonoidea and Belemnitida but direct evidence is missing.

203 Taking the direct fossil evidence from the Jurassic into account, it appears likely that ammonites

204 also played a role as micropredators feeding on early juvenile ammonite offspring (Jäger \&

205 Fraaye, 1997; Klug \& Lehmann, 2015; Keupp, 2012; Kruta et al. 2011; Keupp \& Schweigert,

206 2015; Keupp et al., 2016).

207 The extreme differences in size (up to three orders in magnitude) between adults and juveniles

208 in large ammonites indicate that the range of potential predators changed significantly throughout

209 the life history of these cephalopods. As hatchlings and small juvenile planktonic forms,

210 moderate-sized to large suspension feeders and small predators likely used them as a food source

211 but for adult puzosiids and other large ammonites, only large predators such as mosasaurs,

212 pliosaurs and large fishes can be considered, although the seeming direct evidence for such a

213 trophic relationship is still under debate (Kauffman \& Kesling, 1960; Tsujita \& Westermann,

214 2001; Kauffman, 2004; Gale et al., 2017). Latest Cretaceous juvenile ammonites were possibly

215 not the primary food source of ichthyosaurs since the latter became extinct already in the

216 Cenomanian and are unknown from stomach contents to our knowledge. After the demise of

217 ichthyosaurs, ammonites persisted to be diverse and abundant. In spite of a better link of their

218 extinction with that of the belemnites in the North Pacific near the end of the Early Cretaceous

219 (Iba et al. 2011), belemnite decline in the Tethys at the Cenomanian-Turonian boundary (Doyle,

220 1992; Christensen, 2002) and direct evidence for a trophic relationship between phragmocone-

221 bearing coleoids and ichthyosaurs (Kear et al., 1995, and references therein), Acikkol (2015)

222 suggested that a link between the severe reduction of belemnite diversity and ichthyosaur

223 extinction is unlikely. 
224 An additional point we want to raise is the role of adult ammonites as micropredators feeding

225 on juvenile ammonites. It has been claimed by various authors that ammonites, particularly

226 heteromorphs, lived in the water column (Cеcca, 1997; Guex, 2006), i.e. with direct access to

227 meso- and microplankton. As pointed out above, a microphagous diet has been shown for several

228 ammonite species including heteromorphs (Jäger \& Fraaye, 1997; Klug \& Lehmann, 2015;

229 Keupp, 2012; Kruta et al., 2011; Keupp \& Schweigert, 2015; Keupp et al. 2016), thus making

230 ammonites as predators feeding on juvenile ammonites in the Cretaceous likely.

231

232

Which groups filled the ecospace freed by the extinction of ammonite hatchlings

233 and planktivorous actinopterygians?

234 Association of the extinctions of large marine reptiles, large planktivorous fish and those of

235 ammonites and belemnites suggest trophic relationships between these groups; their extinction

236 freed ecospace for both small zooplankton and various suspension feeders as well as predators.

237 This association is followed by major changes in the planktonic realm such as the rise of

238 holoplanktonic gastropods. Although a few Early Jurassic to Cretaceous heteropods are known

239 (Bandel \& Hemleben, 1995; Nützel, 2014; Teichert \& Nützel, 2015; Janssen \& Goedert, 2016;

240 Nützel et al. 2016; Burridge et al., 2017; Janssen \& Peijnenburg, 2017), the major expansion of

241 heteropods and 'pteropods' falls into the Cenozoic (Lalli \& Gilmer, 1989; Tracey et al., 1993;

242 Janssen et al., 2016; Janssen \& Peijnenburg, 2013).

243 In size and their coiled form, many fossil Limacinidae (Thecosomata, planktonic

244 opisthobranch gastropods) resemble ammonites. Similarly, the conchs of fossil Creseidae

245 morphologically and in size (at least roughly) correspond to hatchlings of belemnites, diplobelids

246 and other phragmocone-bearing coleoids of the Cretaceous (Bandel et al., 1984; Lokho \& Kumar,

247 2008). In addition to these morphologic similarities, these groups shared the planktonic habitat.

248 According to Janssen \& King (1988, 2013), 'pteropods' were already present at least as early as 
249 the latest Palaeocene (see also Janssen et al., 2016). Janssen \& Goedert (2016) even claimed a

250 Cretaceous origin of the Thecosomata. A number of Eocene pteropod occurrences are known

251 worldwide (Bristow et al., 1980; King, 1981; Curry, 1982; Zorn, 1991; Hodgkinson et al., 1992;

252 Janssen et al., 2007; Lokho \& Kumar, 2008; Ando et al., 2009; Cahuzac \& Janssen, 2010). An

253 early Palaeogene origin is also supported by a combination of palaeontological and molecular

254 clock data published by Corse et al. (2013). Remarkably, the latter authors compare the uncoiling

255 of the conch of Thecosomata with the coiling of ammonites, but they did not discuss

256 macroecological implications such as the ecological replacements suggested here. As far as

257 abundance of these fossils is concerned, pteropods are much less frequent than subadult to adult

258 ammonites and belemnites, while their hatchlings are similarly rare. This is probably due to the

259 combination of their small body size as well as their thin and fragile aragonitic shells (Janssen \&

260 King, 1988), which did not provide a high fossilization potential. The great majority of these thin

261 aragonitic shells was undoubtedly rapidly dissolved during early diagenesis and as a consequence

262 not fossilized (Berner, 1977; Janssen \& Peijnenburg, 2017). Nevertheless, the fact that numerous

263 pteropods have been reported from the Eocene implies that they were abundant and widely

264 distributed at least since that period of time.

265 Similarities in size, overall morphology, habitat, abundance as well as the timing of their

266 respective extinction and origination suggest that hatchlings and small individuals of ammonites

267 as well as belemnites were ecologically replaced, at least partially, by planktonic opisthobranchs

268 (Thecosomata) and other holoplanktonic gastropods. In turn, the ecological installation of the

269 Thecosomata together with other planktonic organisms contributed to the dietary basis for the

270 evolution of new groups of large planktivorous suspension feeders (Lalli \& Gilmer, 1989;

271 Armstrong et al. 2005; Hunt et al. 2008). As suggested by Friedman et al. (2010), the Cretaceous

272 'giant planktivorous bony fishes' found an ecological replacement in both large suspension-

273 feeding chondrichthyans and baleen whales. Several of these groups are known to take in 
274 important amounts of planktonic gastropods, although arthropods, krill and other plankton plays

275 important roles as well. Today, thecosomes may regionally contribute up to $50 \%$ of the

276 zooplanktonic biomass and thus are ecologically important (Mackas \& Galbraith, 2012).

277 However, today's Manta rays (Mobulidae) are known to feed predominantly on small

278 Crustaceans, small fish and other plankton and the same holds true for several baleen whales

279 (e.g., Sims \& Merrett, 1997; Motta et al. 2010; Parra Venegas et al., 2011; Slater et al., 2017).

280 Nevertheless, it is unknown what exactly these Palaeogene suspension feeders ate, but at least the

281 filter mesh spacing of both planktivorous chondrichthyans and several baleen whales fits well

282 with the size range of thecosomes (Fig. 3). Also, it is conceivable that early filter feeding species

283 of these groups did not discriminate in their planktonic diet as much as more derived modern

284 relatives. In any case, the niche of filterers catching prey of a size of a few millimetres was

285 occupied by the chondrichthyan and marine mammal filter feeders mentioned above. The

286 Thecosomata example can thus be understood as an example for the new plankton that occurred

287 after the end-Cretaceous mass extinction.

\section{What caused this ecological replacement?}

290 The fossil record comprises quite a few cases of ecological replacements (which are often called

291 'biotic replacements'; e.g., Benton, 1987, 1991; Briggs, 1998). Some famous examples include

292 replacements of brachiopods by bivalves (Gould \& Calloway, 1980; Payne et al., 2014),

293 dinosaurs by mammals (e.g., Sloan et al,. 1986), hybodonts by modern sharks (Schaeffer, 1965),

294 and 'straight-necked' turtles by 'flexible-neck' turtles (Rosenzweig \& McCord, 1991; for a

295 comprehensive list of ecological replacement, see Benton, 1987, 1991). These examples are also

296 used to discuss possible mechanisms, which explain what drove the replacement and in turn,

297 facilitated speciation or macroevolution of clades. Benton (1991) presented several models of

298 ecological replacements, in which the role of competition, key adaptation and mass extinction 
299 was discussed as main cause of such replacements. He concluded that 'competition' and 'key

300 adaptation' can rarely be the main cause of such replacements, although the role of mass

301 extinction also needs to be further examined. By contrast, some other researchers have different

302 views on mechanisms of ecological replacements. For instance, Rosenzweig \& McCord (1991)

303 wrote the following: "species from the new clade produce new species to replace already extinct

304 species from the old clade. The key adaptation gives them a higher competitive speciation rate

305 than old-clade sources of replacement." They presented the example of the straight-necked turtles

306 (Amphichelydia), which were replaced by cryptodiran turtles with the capability of neck

307 retraction and termed this model of replacement 'incumbent replacement'. In this mechanism,

308 key adaptations play a major role. Also, Briggs (1998) argued that several cases of ecological

309 replacement, which are cited as evidence for mass-extinction-induced replacements, took place

310 over a long period of time, and thus biological interaction played a primary role.

311 In the case of ammonoids and belemnites being ecologically replaced by holoplanktonic

312 gastropods, it partially depends on the phylogenetic and temporal scale that is examined and on

313 the fossil record. When focusing only on ammonoids and belemnites, no species remained after

314 the Cretaceous to compete with Palaeogene holoplanktonic gastropods. By contrast, when

315 including the whole clade, this looks different since cephalopods continued to exist and

316 gastropods were also present long before this faunal change (Fig. 5; Sepkoski, 1981). What makes

317 this more relevant is the end-Cretaceous diversity reduction among the Cephalopoda in a phase

318 where the whole clade Gastropoda diversified (a longterm process that started already in the

319 Triassic, which was largely result of the expansion of Neogastropda). Naturally, both

320 Cephalopoda and Gastropoda contain species with a broad range of different modes of life and

321 thus, their differing diversity patterns cannot be explained by the ecological replacement of

322 juvenile ammonites by holoplanktonic gastropods alone- especially although holoplanktonic

323 gastropods are abundant and widely distributed, their diversity is not high. On the other hand, the 
324 removal of ammonites and belemnites from the planktonic realm offered certain gastropods the

325 opportunity to flourish in this realm and to long for new opportunities including availability of

326 food and space resources.

327 As far as key adaptations (e.g., Simpson 1943; Benton, 1983, 1987; Rosenzweig \& McCord,

328 1991; Briggs, 1998; Payne et al. 2014) are concerned, they were already present in the group of

329 species assuming the ecological role of the previously incumbent species after their extinction

330 (Rosenzweig \& McCord, 1991). Although some researchers report the presence of holoplanktonic

331 gastropods in the Cretaceous (Janssen \& Goedert, 2016; Burridge et al., 2017), to date, there is

332 no fossil evidence, which suggests that they acquired all key adaptations that ensured the success

333 of radiation in the Cenozoic except the small, thin-shelled conch. Also, due to a lack of data, it is

334 not possible yet to conclude whether or not a direct biotic interaction between the old (ammonite

335 and belemnite hatchlings) and the new (holoplanktonic gastropods) clades occurred in the

336 Cretaceous, although the Thecosomata originated already in the late Campanian (Janssen \&

337 Goedert, 2016; Burridge et al., 2017). At least, the fossil record suggests that this case of

338 replacement was triggered by a mass extinction event. In Figure 6, we show the distribution of

339 sizes of embryonic conchs of ammonites compared to the earliest occurrences of Thecosomata in

340 the fossil record showing the size-overlap between the two groups. Moreover, the evolution of a

341 holoplanktonic mode of life is particularly easy in gastropods with a planktotrophic veliger larva.

342 Bandel et al. (1984) have convincingly shown that pteropods evolved through neotenic extension

343 of larval life of a benthic ancestor. A similar model has been proposed by Teichert \& Nützel

344 (2015) for Jurassic heteropods which are superabundant in the Early Jurassic Posidonia Shale.

345 Here, repeated Early Jurassic Anoxia resulted in neotenic prolongation of larval life to a

346 holoplanktonic adult life. Thus, the free-swimming veliger larvae may be seen as an

347 preadaptation for a holoplanktonic mode of life in these gastropods and this way the timely

348 overlap that is required for in the incumbency model applies. 
349 Nevertheless, the main radiation of the Thecosomata appears delayed until the Palaeocene-

350 Eocene boundary judging from their fossil record (Janssen et al., 2007; Janssen \& Peijnenburg,

351 2017). This raises the question whether this delay in radiation is an artefact of the poor fossil

352 record of the Thecosomata or whether the main radiation really occurred several million years

353 after the Cretaceous. Considering that a species loss caused by a mass extinction event can

354 require as long as 5-10 My for community recovery (Copper, 1989), it appears likely that the

355 radiation of holoplanktonic gastropods began in the Palaeocene. It must be taken into account

356 that adaptation to the new life style including optimization of resource exploitation needed time.

357 Although we cannot rule out key adaptations and biotic interaction as main causes of the

358 ecological exchange of ammonites and belemnites by Thecosomata and other holoplantonic

359 gastropods after the Cretaceous, it is probably safe to claim that the holoplanktonic gastropods

360 opportunistically benefited from the ecospace vacated by the extinction of these two groups of

361 cephalopods. Possibly, new finds of holoplanktonic gastropods from the early Palaeocene will

362 push their radiation back in time closer to the extinction of ammonoids.

\section{CONCLUSIONS}

365 Large Late Cretaceous ammonites such as puzosiids reached sizes exceeding two meters in

366 diameter. Their offspring has a conch size that is in stark contrast to the adult size; the embryonic

367 conchs of many Cretaceous ammonites measure only about $1 \mathrm{~mm}$ in diameter at the time of

368 hatching. This size relationship, conch geometry and anatomical proportions allow estimates of

369 the number of offspring per female. Accordingly, the largest females might have laid between

$37010^{\prime} 000 ` 000$ (semelparity, small gonads) and 100'000’000 eggs (iteroparity, large gonads). Apart

371 from this extreme example, the great abundance of ammonites, many of them of considerable

372 size as adults, throughout the Mesozoic and the generally small size of their offspring implies that

373 juvenile ammonites and belemnites played a fundamental role near the base of Mesozoic food 
374 webs, both as primary consumers and as food source for secondary consumers. We assume that

375 Mesozoic oceans were full of small hatchlings and juveniles of ammonites and belemnites in the

$376 \mathrm{~mm}$ to $\mathrm{cm}$ size range. This part of the planktonic food chain vanished with the extinction of

377 ammonites and belemnites but may have enabled the evolutionary and ecological rise of

378 holoplanktonic gastropod, which occupy a similar size range, conch morphologies (coiled and

379 straight) and trophic role. This underlines the importance of ecological differentiation between

380 different ontogenetic stages. Gill raker filament spacing in huge pachycormids correspond in size

381 to these juvenile ammonites and belemnites, potentially suggesting a trophic link in the light of

382 the synchronous extinction at the end of the Cretaceous.

383 Here, we suggest that the ecospace formerly occupied by ammonite and belemnite juveniles

384 was taken over during the post-Mesozoic rise of the the Thecosomata (holoplanktonic

385 heterobranchs) and other holoplanktonic gastropods. The ecological replacement of the

386 pachycormids is a bit more difficult to explain. During the early Palaeogene, three important

387 large planktivorous lineages of chondrichthyans occur; however, modern mobulids (Manta rays),

388 for instance, are known to feed on planktonic Crustaceans. Perhaps, stomach contents of

389 exceptionally preserved specimens of Palaeogene planktivorous chondrichthyans will shed more

390 light on the suspension feeders that, at least in their function as primary consumers, benefited

391 from the thecosomes that ecologically replaced juvenile ammonites. In any case, it is likely that

392 ammonite hatchlings had occupied a significant part of their particular plankton size class and

393 were important prey for some filter feeders. This size class niche of small plankton was vacant

394 after the Cretaceous and holoplanktonic gastropods are one important group filling this ecospace,

395 probably in concert with other plankton.

396 Independent of the filter feeder-side, we conclude that in r-strategists, the young offspring can

397 play a more important ecological role than their large adults. This case of ecological replacement 
398 underlines the significance of differences at which developmental stage the acme in ecological

399 importance of an organism occurs.

400

401 Acknowledgements

402 Jakob Vinther (Bristol) generously provided an illustration, which was a valuable basis for one of 403 our illustrations. We thank C. Steinweg, L. Schöllmann and J.-O. Kriegs (all Münster), Kishor 404 Kumar (Uttarakhand, India), Kazushige Tanabe (Tokyo), and Klaus Bandel (Hamburg) for 405 providing illustrations and allowing us to use them. We greatly appreciate the input of the 406 reviewers (Margaret Yacobucci, Bowling Green State University and two anonymous reviewers) 407 and the editor Kenneth De Baets (Erlangen). 
408

409

410

411

412

413

414

415

416

417

418

419

420

421

422

423

424

425

426

427

428

429

430

431

432

\section{REFERENCES}

Acikkol, N. 2015. Testing the Cretaceous diversity of ichthyosaurs and their extinction Hypotheses using a quantitative approach. Degree project at the Department of Earth Sciences. 40 pp. Uppsala University, Uppsala.

Alvarez, L.W., Alvarez, W., Asaro, F. \& Michel, H.V. 1980. Extraterrestrial cause for the Cretaceous-Tertiary extinction. Science 208: 1095-1108.

Ando, Y. Ujihara, A. \& Ichihara, T. 2009. First occurrence of Paleogene pteropods (Gastropoda; Thecosomata) from Japan. JourNal of the Geological SocIety of Japan 115: 187190.

Archibald, D. \& Fastovsky, D. 2004. Dinosaur extinction. In: Weishampel, D. B., Dodson, P. \& Osmólska, H. (eds) The Dinosauria (2 ${ }^{\text {nd }}$ ed.). 672-684. Berkeley: University of California Press.

Arkhipkin, A.I. \& Laptikhovsky, V.V. 2012. Impact of ocean acidification on plankton larvae as a cause of mass extinctions in ammonites and belemnites. Neues Jahrbuch für Geologie und Paläontologie, Abh. 266: 39-50.

\section{Armstrong, J.L., Boldt, J.L., Cross, A.D., Moss, J.H., Davis, N.D., Myers, K.W., Walker,} R.V., Beauchamp, D.A. \& Haldorson, L.J. 2005. Distribution, size, and interannual, seasonal and diel food habits of northern Gulf of Alaska juvenile pink salmon, Oncorhynchus gorbuscha. Deep Sea Research Part II: Topical Studies in Oceanography 52:247-265.

Bandel, K., Engeser, T. \& Reitner, J. 1984. Embryonic development of Hibolithes (Belemnitida, Cephalopoda). Neues Jahrbuch für Geologie und Paläontologie,Abh. 167: 275303.

Bandel, K., Almogi-Labin, A., Hemleben, C. \& Deuser, W.G. 1984. The conch of Limacina and Peraclis (Pteropoda) and a model for the evolution of planktonic gastropods. Neues Jahrbuch für Geologie und Paläontologie, Abhandlungen 168: 87-107. 
433 Bandel, K. \& Hemleben, C. 1995. Observations on the ontogeny of thecosomatous pteropods

434 (holoplanktic Gastropoda) in the southern Red Sea and from Bermuda. Marine Biology 124:

$435 \quad 225-243$.

436 Benton, M.J. 1983. Large-scale replacements in the history of life. Nature 302:16-17.

437 Benton, M.J. 1987. Progress and competition in macroevolution. Biological Reviews of the $438 \quad$ Cambridge Philosophical Society 62:305-338.

439 Berner, R.A. 1977. Sedimentation and dissolution of pteropods in the ocean. 243-260. In:

440 Andersen, R.T. \& Malahoff, A. (eds), The fate of fossil fuel CO2 in the oceans. Plenum, New $441 \quad$ York.

442 Briggs, J.C. 1998. Biotic replacements: Extinction or clade interaction? Bioscience 48: 389-395. 443 Bristow, C.R., Ellison, R.A., \& Wood, C.J. 1980. The Claygate Beds of Essex. ProcEedings of 444 the Geological Association 91: 261-277.

445 Burridge, A.K., Hörnlein, C., Janssen, A.W., Hughes, M., Bush, S.L., Marlétaz, F., Gasca, 446 R., Pierrot-Bults, A.C., Michel, E., Todd, J.A., Young, J.R., Osborn, K.J., Menken, S.B.J. 447 \& Peijnenburg, K.T.C.A. 2017. Time-calibrated molecular phylogeny of pteropods. PLoS 448 ONE 12: 0177325.

449 Cahuzac, B. \& Janssen, A.W. 2010. Eocene to Miocene holoplanktonic Mollusca (Gastropoda) 450 of the Aquitaine Basin, southwest France. Scripta Geologica 141: 1-193.

451 Cecca, F. 1997. Late Jurassic and Early Cretaceous uncoiled ammonites: trophism-related 452 evolutionary processes. Comptes Rendus de l'Académie des Sciences, Ser. IIA, Earth and 453 Planetary Science 325: 629-634.

454 Christensen, W.K. 2002. Palaeobiology, phylogeny and palaeobiogeography of belemnoids and 455 related coleoids. Berliner paläobiologische Abhandlungen 1: 18-21.

456 Copper, P. 1989. Enigmas in Phanerozoic reef development. Fossil Cnidaria, 5, 371-385. 
457 Corse, E., Rampal, J., Cuoc, C., Pech, N., Perez, Y.\& Gilles, A. 2013. Phylogenetic analysis

458 of Thecosomata Blainville, 1824 (holoplanktonic Opisthobranchia) using morphological and

459 molecular data. PLOS ONE 8, e59439: 1-20.

460 Curry, D. 1982. Ptéropodes éocènes de la tuilerie de Gan (Pyrénées-Atlantiques) et de quelques

461 autres localités de SW de la France. Cahiers de Micropaléontologie 4(for 1981): 35-44.

462 De Baets, K., Klug, C., Korn, D. \& Landman, N.H. 2012. Early evolutionary trends in

463 ammonoid embryonic development. Evolution 66:1788-1806.

464 De Baets, K., Landman, N.H. \& Tanabe, K. 2015. Ammonoid embryonic development. In:

465 Klug, C., Korn, D., De Baets, K., Kruta, I. \& Mapes, R.H. (eds), Ammonoid paleobiology:

466 from anatomy to paleoecology. 113-205 Dordrecht: Springer.

467 Doguzhaeva, L.A., Weis, R., Delsate, D. \& Mariotti, N. 2014. Embryonic shell structure of

468 Early-Middle Jurassic belemnites, and its significance for belemnite expansion and

469 diversification in the Jurassic. Lethaia 47: 49-65.

470 Doyle, P.A. 1992. Review of the biogeography of Cretaceous belemnites: Palaeogeography,

471 Palaeoclimatology, Palaeoecology 92: 207-216.

472 Foster, W.J. \& Twitchett, R.J. 2014. Functional diversity of marine ecosystems after the Late

473 Permian mass extinction event. Nature geoscience 7: 233-238.Friedman, M., Shimada, K.,

474 Martin, L.D., Everhart, M.J., Liston, J., Maltese, A. \& Triebold, M. 2010. 100-million-

475 year dynasty of giant planktivorous bony fishes in the Mesozoic seas. Science 327: 990-993.

476 Gale, A.S., Kennedy, W.J. \& Martill, D. 2017. Mosasauroid predation on an ammonite -

477 Pseudaspidoceras - from the Early Turonian of south-eastern Morocco. Acta Geologica

478 Polonica 67: 31-46. DOI: https://doi.org/10.1515/agp-2017-0003.

479 Goolaerts, S. 2010. Late Cretaceous ammonites from Tunisia: chronology and causes of their

480 extinction and extrapolation to other areas. Aardkundige Mededelingen 21: 1-220. 
481 Gould, S. J., \& Calloway, C. B. 1980. Clams and brachiopods—ships that pass in the night. 482 Paleobiology, 6: 383-396.

483 Guex, J. 2006. Reinitialization of evolutionary clocks during sublethal environmental stress in 484 some invertebrates. Earth and Planetary Science Letters 242: 240-253.

485 Hautmann, M. 2014. Diversification and diversity partitioning. Paleobiology 40, 162-176.

486 Hodgkinson, K.A., Garvie, C.L. \& Bé, A.W.H. 1992. Eocene euthecosomatous Pteropoda 487 (Gastropoda) of the Gulf and eastern coasts of North America. Bulletin of American 488 Paleontology 103: 5-62.

489 Hoffmann, R. \& Keupp, H. 2015. Ammonoid paleopathology. In: Klug, C., Korn, D., De Baets, 490 K., Kruta, I. \& Mapes, R.H. (eds), Ammonoid paleobiology, Volume I: from anatomy to 491 ecology. Topics in Geobiology 43: 877-926 Dordrecht: Springer.

492 Hofmann, R., Hautmann, M., Brayard, A., Nützel, A. Bylund, K.G., Jenks, J.F., Vennin, E., 493 Olivier, N. \& Bucher, H. 2014. Recovery of benthic marine communities from the end494 Permian mass extinction at the low-latitudes of Eastern Panthalassa. Palaeontology 57: 547$495 \quad 558$.

Hönisch, B., Ridgwell, A., Schmidt, D.N., Thomas, E., Gibbs, S.J., Sluijs, A., Zeebe, R., Kump, L., Martindale, R.C., Greene, S.E., Kiessling, W., Ries, J., Zachos, J.C., Royer, D.L., Barker, S., Marchitto Jr., T.M., Moyer, R., Pelejero, C., Ziveri, P., Foster, G.L. \& Williams, B. 2012. The geological record of ocean acidification. Science 335: 1058-1063.

$500 \quad$ DOI: $10.1126 /$ science. 1208277

501 Hunt, B.P.V., Pakhomov, E.A., Hosie, G.W., Siegel, V., Ward, P. \& Bernard, K. 2008. 502 Pteropods in Southern Ocean ecosystems. Progress in Oceanography 78: 193-221.

503 Iba, Y., Mutterlose, J., Tanabe, K., Sano, S., Misaki, A. \& Terabe, K. 2011. Belemnite 504 extinction and the origin of modern cephalopods 35 m.y. prior to the Cretaceous-Paleogene 505 event. Geology 39: 483-486. 
506 Jablonski, D. 2008. Extinction and the spatial dynamics of biodiversity. PNAS USA 105: 11528$507 \quad 11535$.

508 Jablonski, D. \& Raup, D.M. 1994. Selectivity of end-Cretaceous marine bivalve extinctions.

$509 \quad$ Science 268: 389-391.

510 Jacobs, D.K. 1992. Shape, drag, and power in ammonoid swimming. Paleobiology 18: 203-220.

511 Jacobs, D.K. \& Chamberlain, J.A. 1996. Buoyancy and hydrodynamics in ammonoids. In:

512 Landman, N.H., Tanabe K. \& Davis, R.A. (eds), Ammonoid paleobiology. Topics in

513 geobiology 13. Plenum, New York.

514 Jäger, M. \& Fraaye, R. 1997. The diet of the Early Toarcian ammonite Harpoceras falciferum.

515 Palaeontology 40:557-574.

516 Janssen, A.W. \& Goedert, J.L. 2016. Notes on the systematics, morphology and biostratigraphy

517 of fossil holoplanktonic Mollusca, 24. First observation of a genuinely Late Mesozoic

518 thecosomatous pteropod. Basteria 80: 59-63.

519 Janssen, A.W. \& King, C. 1988. Planktonic mollusks (pteropods). In: Vinken, R. (ed), The

520 Northwest European Tertiary Basin, Results of the International Geological Correlation

521 Programme Project no. 124. Geol. Jahrb. 100: 356-368.

522 Janssen, A.W. \& Peijnenburg, K.T.C.A. 2013. Holoplanktonic Mollusca: development in the

523 Mediterranean Basin during the last $30 \mathrm{Ma}$ and their future. In: Goffredo, S. \& Dubinsky, Z.

524 (eds), The Mediterranean Sea. Its history and present challenges. 341-362. Dordrecht:

525 Springer.

526 Janssen, A.W. \& Peijnenburg, K.T.C.A. 2017. An overview of the fossil record of Pteropoda

527 (Mollusca, Gastropoda, Heterobranchia). Cainozoic Research 17:3-10.

528 Janssen, A.W., Schnetler, K.I. \& Heilmann-Clausen, C. 2007. Notes on the systematics

529 morphology and biostratigraphy of fossil holoplanktonic Mollusca, 19. Pteropods 
530 (Gastropoda, Euthecosomata) from the Eocene Lillebaelt Clay Formation (Denmark, Jylland).

$531 \quad$ Basteria 71: 157-168.

532 Janssen, A.W., Sessa, J.A. \& Thomas, E. 2016. Pteropoda (Mollusca, Gastropoda,

533 Thecosomata) from the Paleocene-Eocene Thermal Maximum (United States Atlantic Coastal

534 Plain). Palaeontologia Electronica 19:1-26.

535 Jarman, S.N. 2001. The evolutionary history of krill inferred from nuclear large subunit rDNA 536 sequence analysis. Biological Journal of the Linnean Society 73: 199-212.

537 Kauffman, E.G. 2004. Mosasaur predation on Upper Cretaceous nautiloids and ammonites from 538 the United States Pacific Coast. Palaios 19:96-100.

539 Kauffman, E.G. \& Kesling, R.V. 1960. An Upper Cretaceous ammonite bitten by a mosasaur.

$540 \quad$ Contributions of the Michigan Univiversity, Museum of Paleontology 15: 193-248.

541 Kear, A.J., Briggs, D.E.G. \& Donovan, D.T. 1995. Decay and fossilization of non-mineralized

542 tissue in coleoid cephalopods. Palaeontology 38: 105-131.

543 Keller, G., Abramovich, S., Berner, Z. \& Adatte, T. 2009. Biotic effects of the Chicxulub

544 impact, K-T catastrophe and sea level change in Texas. Palaeogeography, Palaeoclimatology,

545 Palaeoecology 271: 52-68.

546 Kennedy, W.J. 1989. Thoughts on the evolution and extinction of Cretaceous ammonites.

547 Proceedings of the Geological Association 100: 251-279.

548 Kennedy, W.J. 1993. Ammonite faunas of the European Maastrichtian; diversity and extinction.

549 In: House, M. R. (ed) The Ammonoidea: environment, ecology, and evolutionary change.

$550 \quad$ Systematics Association Spec. Vol. 47: 285-326.

551 Kennedy, W.J. \& Kaplan, U. 1995. Parapuzosia (Parapuzosia) seppenradensis (Landois) und

552 die Ammonitenfauna der Dülmener Schichten, unteres Unter-Campan, Westfalen. Geologie

553 und Paläontologie in Westfalen 33: 1-127. 
554 Keupp, H. 2012. Atlas zur Paläopathologie der Cephalopoden. Berliner paläobiolOgische

555 Abhandlungen 12: 1-390.

556 Keupp, H., Hoffmann, R., Stevens, K. \& Albersdörfer, R. 2016. Key innovations in Mesozoic

557 ammonoids: the multicuspidate radula and the calcified aptychus. Palaeontology 59:775-791.

558 Keupp, H. \& Schweigert, G. 2015. Kopffüßer (Cephalopoda). In: Arratia, G., Schultze, H.-P.,

559 Tischlinger, H. \& Viohl, G. (eds): Solnhofen. Ein Fenster ind die Jurazeit. 218-238. Pfeil,

560 München.

561 King, C. 1981. The stratigraphy of the London Clay. Tertiary Research Spec. Pap. 6: 1-158.

562 Klug, C. \& Lehmann, J. 2015. Soft part anatomy of ammonoids: reconstructing the animal

563 based on exceptionally preserved specimens and actualistic comparisons. In: Klug, C., Korn,

564 D., De Baets, K., Kruta, I. \& Mapes, R. H. (eds): Ammonoid paleobiology, Volume I: from

565 anatomy to ecology. Topics in Geobiology 43: 539-552. Dordrecht: Springer.

566 Klug, C., De Baets, K. \& Korn, D. 2016. Exploring the limits of morphospace: ontogeny and

567 ecology of Late Viséan ammonoids from the Tafilalt (Morocco). Acta Palaeontologica

$568 \quad$ Polonica 61: 1-14.

569 Klug, C., Riegraf, W. \& Lehmann, J. 2012. Soft-part preservation in heteromorph ammonites

570 from the Cenomanian-Turonian Boundary Event (OAE 2) in the Teutoburger Wald (Germany).

$571 \quad$ Palaeontology 55: 1307-1331.

572 Korn, D. \& Klug, C. 2007. Conch form analysis, variability, and morphological disparity of a

573 Frasnian (Late Devonian) ammonoid assemblage from Coumiac (Montagne Noire, France).

574 In: Landman, N. H., Davis, R. A., Manger, W. \& Mapes, R. H. (eds), Cephalopods - Present

575 and Past. 57-86. Dordrecht: Springer.

576 Kruta, I., Landman, N.H., Rouget, I., Cecca, F. \& Tafforeau, P. 2011. The role of ammonites

577 in the marine Mesozoic food web revealed by jaw preservation. Science 311: 70-72. 
578 Lalli, C.M. \& Gilmer, R.W. 1989. Pelagic snails: the biology of holoplanktonic gastropod

579 mollusks. 276 pp. Stanford University Press.

580 Landman, N.H., Goolaerts, S., Jagt, J.W.M., Jagt-Yazykova, E.A., \& Machalski, M. 2015.

581 Ammonites on the brink of extinction: diversity, abundance, and ecology of the Order

582 Ammonoidea at the Cretaceous/Paleogene (K/Pg) boundary. In: Klug, C., Korn, D., De Baets,

583 K., Kruta, I. \& Mapes, R.H. (eds), Ammonoid paleobiology: from macroevcolution to

584 paleogeography. Topics in Geobiology 44: 497-553. Dordrecht: Springer.

585 Landman, N.H., Goolaerts, G., Jagt, J.W.M., Jagt-Yazykova, E.A., Machalski, M.,

586 Yacobucci, M.M. 2014. Ammonite extinction and nautilid survival at the end of the

$587 \quad$ Cretaceous. Geology 42: 707-710.

588 Landman, N.H., Tanabe, K. \& Shigeta, Y. 1996. Ammonoid embryonic development. In:

589 Landman, N.H., Tanabe, K. \& Davis, R.A. (eds), Ammonoid Paleobiology. New York:

$590 \quad$ Plenum.

591 Landois, H. 1895. Die Riesenammoniten von Seppenrade, Pachydiscus Zittel seppenradensis II.

592 Landois. Jahresbericht der Zoologischen Section des Westfälischen Provinzial-Vereins für

$593 \quad$ Wissenschaft und Kunst 23: 99-108.

594 Laptikhovsky, V., Nikolaeva, S. \& Rogov, M. 2017. Cephalopod embryonic shells as a tool to

595 reconstruct reproductive strategies in extinct taxa. Biological Reviews of the Cambridge

$596 \quad$ Philosophical Society: 14 pp. 1 DOI: 10.1111/brv.12341

597 Lehmann, U. 1981. Ammonite jaw apparatus and soft parts. In: House, M. R. \& Senior, J. R.

598 (eds), The Ammonoidea. SystEmatics Association Spec. Pap. 18: 275-287.

599 Lehmann, U. 1985. Zur Anatomie der Ammoniten: Tintenbeutel, Kiemen, Augen.

600 Paläontologische Zeitschrift. 59: 99-108.

601 Lokho, K. \& Kumar, K. 2008. Fossil pteropods (Thecosomata, holoplanktonic Mollusca) from

602 the Eocene of Assam-Arakan Basin, northeastern India. Current Science 94: 647-652. 
603 Mackas, D.L. \& Galbraith, M.D. 2012. Pteropod time-series from the NE Pacific. ICES

$604 \quad$ Journal of Marine Science 69: 448-459.

605 Mapes, R.H. \& Nützel, A. 2009. Late Palaeozoic mollusc reproduction: cephalopod egg-laying

606 behavior and gastropod larval palaeobiology. Lethaia 42: 341-356.

607 Marshall, C.R. \& Ward, P.D. 1996. Sudden and gradual molluscan extinctions in the latest

608 Cretaceous in western European Tethys. Science 274:1360-1363.

609 McGhee, G.R. Jr., Clapham, M.E., Sheehan, P.M., Bottjer, D.J. \& Droser, M.L. 2013. A new

610 ecological-severity ranking of major Phanerozoic biodiversity crises. Palaeogeography,

611 Palaeoclimatology, Palaeoecology 370: 260-270.

612 Miller, K.G., Sherrell, R.M., Browning, J.V., Field, M.P., Gallagher, W., Olsson, R.K.,

613 Sugarman, P.J., Tuorto, S. \& Wahyudi, H. 2010. Relationship between mass extinction and

614 iridium across the Cretaceous-Paleogene boundary in New Jersey. Geology 38: 867-870.

615 Mironenko, A.A., \& Rogov, M.A. 2015. First direct evidence of ammonoid ovoviviparity.

$616 \quad$ Lethaia, DOI: 10.1111/let.12143.

617 Motta, P.J., Maslanka, M., Hueter, R.E., Davis, R.L., de la Parra, R., Mulvany, S.L.,

618 Habegger, M.L., Strother, J.A., Mara, K.R., Gardiner, J.M., Tyminski, J.P. \& Zeigler

619 L.D. 2010. Feeding anatomy, filter-feeding rate, and diet of whale sharks Rhincodon typus

620 during surface ram filter feeding off the Yucatan Peninsula, Mexico. Zoology 113:199-212.

621 doi: 10.1016/j.zool.2009.12.001.Naglik, C., Rikhtegar, F.N. \& Klug, C. 2016. Buoyancy in

622 Palaeozoic ammonoids from empirical 3D-models and their place in a theoretical

623 morphospace. Lethaia 49: 3-12.

624 Naglik, C., Tajika, A., Chamberlain, J. \& Klug, C. 2015. Ammonoid locomotion. In: Klug, C.,

625 Korn, D., De Baets, K., Kruta, I. \& Mapes, R.H. (eds.): Ammonoid paleobiology, Volume I:

626 from anatomy to ecology. Topics in Geobiology 43: 657-696. Springer, Dordrecht.

627 Nützel, A. 2014. Larval ecology and morphology in fossil gastropods. Palaeontology 1: 1-25. 
628 Nützel, A. \& Mapes, R.H. 2001. Larval and juvenile gastropods from a Carboniferous black

629 shale: palaeoecology and implications for the evolution of the Gastropoda. Lethaia 34: 143-

$630 \quad 162$.

631 Nützel, A., Schneider, S., Hülse, P., Kelly, S.R.A., Tilley, L. \& Veit, R. 2016. A new Early

632 Jurassic gastropod from Ellesmere Island, Canadian Arctic - an ancient example of

633 holoplanktonic gastropods. Bulletin of Geosciences 91: 229-242.

634 Olivero, E.B. 2012. Sedimentary cycles, ammonite diversity and palaeoenvironmental changes in 635 the Upper Cretaceous Marambio Group, Antarctica. Cretaceous Research 34: 348-366.

636 Olivero, E.B. \& Zinsmeister, W.J. 1989. Large heteromorph ammonites from the Upper

637 Cretaceous of Seymour Island, Antarctica. Journal of Paleontology 63: 626-636.

638 de la Parra Venegas, R., Hueter, R., González Cano, J., Tyminski, J., Gregorio Remolina, J.,

639 Maslanka, M., Ormos, A., Weigt, L., Carlson, B. \& Dove, A. 2011. An Unprecedented

640 Aggregation of Whale Sharks, Rhincodon typus, in Mexican Coastal Waters of the Caribbean

641 Sea. PLoS ONE 6(4): e18994. doi:10.1371/journal.pone.0018994

642 Payne, J.L., Heim, N.A., Knope, M.L. \& McClain, C.R. 2014. Metabolic dominance of

643 bivalves predates brachiopod diversity decline by more than 150 million years. Proceedings of

644 the Royal Society B: Biological Sciences 281: 20133122.

645 http://dx.doi.org/10.1098/rspb.2013.3122.

646 Raup, D.M. \& Chamberlain, J.A. Jr. 1967. Equations for volume and center of gravity in 647 ammonoids shells. Journal of Paleontol. 41: 566-574.

648 Roopnarine, P.D. \& Angielczyk, K.D. 2015. Community stability and selective extinction 649 during the Permian-Triassic mass extinction. Science 350: 90-93.

650 Rosenzweig, M.L. \& McCord, R.D. 1991. Incumbent replacement: evidence for long-term 651 evolutionary progress. Paleobiology 17: 202-213. 
652 Schulte, P., Alegret, L., Arenillas, I., Arz, J.A., Barton, P.J., Bown, P.R., Bralower, T.J.,

653 Christeson, G.L., Claeys, P., Cockell, C.S., Collins, G.S., Deutsch, A., Goldin, T.J., Goto,

654 K., Grajales-Nishimura, J.M., Grieve, R.A.F., Gulick, S.P.S., Johnson, K.R., Kiessling,

655 W., Koeberl, C., Kring, D.A., MacLeod, K.G., Matsui, T., Melosh, J., Montanari, A.,

656 Morgan, J.V., Neal, C.R., Nichols, D.J., Norris, R.D., Pierazzo, E., Ravizza, G.,

657 Rebolledo-Vieyra, M., Reimold, W.U., Robin, E., Salge, T., Speijer, R.P., Sweet, A.R.,

658 Urrutia-Fucugauchi, J., Vajda, V., Whalen, M.T. \& Willumsen, P.S. 2010. The Chicxulub

659 asteroid impact and mass extinction at the Cretaceous-Paleogene Boundary. Science 327:

$660 \quad 1214-1218$.

661 Seilacher, A. 1998. Mosasaurs, limpets or diagenesis: How Placenticeras shells got punctured.

662 MittEilungen des MusEums für Naturkunde, Berlin. Geowissenschaftliche Reihe 1: 93-102.

663 Sepkoski, Jr., J.J. 1981. A factor analytic description of the Phanerozoic marine fossil record.

664 Paleobiology 7: 36-53.Shigeta, Y. 1993. Post-hatching early life history of Cretaceous

665 Ammonoidea. Lethaia 26: 133-145.

666 Simpson, G.G. 1943. Turtles and the origin of the fauna of Latin America. American Journal of

$667 \quad$ Science 241:413-429.

668 Sims, D.W. \& Merrett, D.A. 1997. Determination of zooplankton characteristics in the presence

669 of surface feeding basking sharks Cetorhinus maximus. Marine Ecology Progress Series 158:

$670 \quad 297-302$.

671 Slater, G.J., Price, S.A., Santini, F. \& Alfaro, M.E. 2017. Diversity versus disparity and the

672 radiation of modern cetaceans. Proceedings of the Royal Society B: $8 \mathrm{pp}$.

673 doi:10.1098/rspb.2010.0408

674 Sloan, R.E., Rigby, K., Van Valen, L.M. \& Diane, G. 1986. Gradual dinosaur extinction and

675 simultaneous ungulate radiation in the Hell Creek formation. Science 232: 629-633. 
676 Smit, J. 1982. Extinction and evolution of planktonic formaninifera after a major impact at the

677 Cretaceous/ Tertiary boundary. GSA Special Paper 190: 329-352.

678 Tajika, A., Naglik, C., Morimoto, N., Pascual-Cebrian, E., Hennhöfer, D.K. \& Klug, C.

679 2015. Empirical 3D-model of the conch of the Middle Jurassic ammonite microconch

680 Normannites, its buoyancy, the physical effects of its mature modifications and speculations

681 on their function. Historical Biology 27: 181-191.

682 Tanabe, K., Kulicki, C. \& Landman, N.H. 2008. Development of the embryonic shell structure

683 of Mesozoic ammonoids. American Museum Novitates 3621: 1-19.

684 Tanabe, K. \& Tsukahara, J. 1987. Biometric analysis of Nautilus pompilius from the

685 Philippines and the Fiji Islands. In: Saunders, W.B. \& Landman, N.H. (eds), Nautilus. 105-

686 113. New York: Plenum Press.

687 Teichert, S. \& Nützel, A. 2015. Early Jurassic anoxia triggered the evolution of the oldest

688 holoplanktonic gastropod Coelodiscus minutus by means of heterochrony. Acta

689 Palaeontologica Polonica 60: 269-276.

690 Tobin, T.S., Ward, P.D., Steig, E.J., Olivero, E.B., Hilburn, I.A., Mitchell, R.N., Diamond,

691 M.R., Raub, T.D. \& Kirschvink, J.L. 2012. Extinction patterns, $\delta^{18} \mathrm{O}$ trends, and

692 magnetostratigraphy from a southern high-latitude Cretaceous-Paleogene section: Links with

693 Deccan volcanism. Palaeogeography, Palaeoclimatology, Palaeoecology 350-352: 180-188.

694 Tracey S., Todd, J.A., \& Erwin, D.H. 1993. Mollusca: Gastropoda. In: Benton, M. J. (ed), The

695 Fossil Record. 131-167. Chapman and Hall, London.

696 Tsujita, C.J. \& Westermann, G.E.G. 2001. Were limpets or mosasaurs responsible fort he

697 perforations in the ammonite Placenticeras? Palaeogeography, Palaeoclimatology,

698 Palaeoecology 169: 245-270.

699 Vinther, J., Stein, M., Longrich, N.R. \& Harper, D.A.T. 2014. A suspension-feeding

$700 \quad$ anomalocarid from the Early Cambrian. Nature 507: 496-497. 
701 Walton, S.A., Korn, D. \& Klug, C. 2010. Size distribution of the Late Devonian ammonoid

702 Prolobites: indication for possible mass spawning events. Swiss Journal of Geoscience 103:

703 475-494. DOI 10.1007/s00015-010-0036-y

704 Ward, P.D. \& Signor, P.W. III 1983. Evolutionary tempo in Jurassic and Cretaceous ammonites.

705 Paleobiology 9: 183-198.

706 Ward, P.D. 1996. Ammonoid extinction. In: Landman, N. H., Tanabe, K. \& Davis, R. A. (eds), 707 Ammonoid Paleobiology. Plenum, New York.

708 Ward, P.D. \& Bandel, K. 1987. Life history strategies in fossil cephalopods. 329-352. In: Boyle,

709 P. R. (ed), Cephalopod life cycles II. Academic Press, London.

710 Yacobucci, M.M. 2015. Macroevolution and paleobiogeography of Jurassic-Cretaceous

711 ammonoids. In: Klug, C., Korn, D., De Baets, K., Kruta, I. \& Mapes, R.H. (eds): Ammonoid

712 paleobiology, Volume I: from anatomy to ecology. Topics in Geobiology 43: 539-552.

713 Dordrecht: Springer.

714 Zorn, I. 1991. A systematic account of Tertiary Pteropoda (Gastropoda, Euthecosomata) from

715 Austria. Contributions to Tertiary and Quaternary Geology 28: 95-139. 
716 Table

717 Table 1 Measurements of embryonic conchs of Cretaceous ammonites. Data from De Baets

718 et al. (2015) and Laptikhovsky et al. (2017).

719

720 Table 2. Size of conchs of Thecosomata with coiled conchs. Data sources are indicated in the

721 table.

722

723 Table 3. Size of conchs of Thecosomata with straight conchs. Data sources are indicated in the 724 table.

725

726 Table 4. Estimates of numbers of eggs produced by various ammonoid taxa.

727 
728 Figure Captions

729 Figure 1 Adult ammonites (A-C), juvenile ammonites (D, E), and an embryonic belemnite

730 (F) compared to fossil conchs of Thecosomata from the Eocene of India (G-J). $0.1 \mathrm{~mm}$-scale

731 bare applies to figures D to J. Photo in A courtesy C. Steinweg, L. Schöllmann and J.-O. Kriegs

732 (all Münster); D and E from Tanabe et al. (2008); F from Bandel et al. (1984); G to J from Lokho

733 \& Kumar (2008). A. Parapuzosia seppenradensis, Campanian, Seppenrade. B, C.

734 Pachydesmoceras sp., Campanian, Hokkaido, diameter 1.3 m, D. Aiba (Mikasa) for scale. Note

735 the symmetrical bulges in the posterior body chamber in C. D, juvenile conch of Scaphites

736 whitfieldi, AMNH 44833, Turonian, U.S.A. E, embryonic conch of Aconeceras cf. trautscholdi,

737 UMUT MM 29439-4, Aptian, Russia. F, embryonic conch of Hibolithes sp., GPIT Ce 1599,

738 Callovian, Lithuania. G to J, Upper Disang Formation, Phek District, Nagaland. G, H,

739 Limacinidae spp. I, J, Creseidae spp.

740

741 Figure 2. Relationship between adult conch size and the estimated number of eggs. Data are

742 displayed in Tab. 4. The variation seen in smaller species likely roots in differences of the embryo 743 size.

745 Figure 3 Zooplankton size ranks and filter mesh spacing of planktivorous filter feeders.

746 Modified after Vinther et al. (2014), using data from Lokho \& Kumar (2008), Friedman et al.

747 (2010) and De Baets et al. (2015). The horizontal coloured lines connect the size ranges of

748 zooplanktonic prey organisms with the mesh size of large filter-feeding marine vertebrates. The

749 black lines mark the range in prey size organisms filtered by the respective filter feeders. Note

750 how the size range of hatchlings of ammonites and belemnites match that of Thecosomata and,

751 on the filter feeder-side, that of the mesh-size of the filtering organ.

752

753 Figure 4 Occurrences, extinctions, originations and diversity changes in plankton and large

754 planktotrophic suspension feeders from the Cretaceous to the Palaeogene (mass extinction 
755 marked by red bar). Ammonite and belemnite diversity show the number of species. Data from

756 Friedmann et al. (2010), Bristow et al. (1980), Corse et al. (2013), Yacobucci (2015) and Jarman

757 (2001). Note relative timing of extinctions of cephalopods with small planktonic juveniles and

758 filter feeding bony fish and rediations of holoplanktonic gastropods, krill as well as filter-feeding

759 chondrichthyans and whales.

760

761

762

Figure 5 Diversity of Cephalopoda and Gastropoda through the Phanerozoic. Redrawn after

Sepkoski (1981). Note the diversity reduction in cephalopods at the end of the Cretaceous and the subsequent radiation of gastropods. The Cretaceous Palaeogene mass extinction is marked by the red line.

766

Figure 6 Box plots of Cretaceous ammonitella diameters and Cretaceous to Palaeogene

Thecosomata conch size. Data (Tab. 1) from De Baets et al. (2015), Laptikhovsky et al. (2017),

Lokho \& Kumar (2008), Janssen et al. (2007, 2016), Janssen \& Goedert (2016), and Janssen \& Peijnenburg (2017). The red line marks the Cretaceous-Palaeogene boundary. The numbers

771 below the box plots give the sample size. Orange marks ammonitella data, while green marks

772 gastropod data. Question marks indicate that fossils are present but the values indicate guesses:

773 In the case of Valanginian ammonites, protoconchs are known and from that size, an ammonitella

774 size close to $1 \mathrm{~mm}$ appears likely. In the case of Campanian and late Palaeocene Thecosomata,

775 the only genus ranging back into the Campanian is Heliconoides (Janssen \& Goedert, 2016;

776 Janssen \& Peijnenburg, 2017); Eocene specimens measure approximately $2 \mathrm{~mm}$, hence this size

777 estimate. 


\section{Figure 1}

Adult ammonites $(A-C)$, juvenile ammonites $(D, E)$, and an embryonic belemnite ( $F)$ compared to fossil conchs of Thecosomata from the Eocene of India (G-J).

$0.1 \mathrm{~mm}$-scale bare applies to figures D to J. Photo in A courtesy C. Steinweg, L. Schöllmann and J.-O. Kriegs (all Münster); D and E from Tanabe et al. (2008); F from Bandel et al. (1984); G to J from Lokho \& Kumar (2008). A. Parapuzosia seppenradensis, Campanian, Seppenrade. B, C. Pachydesmoceras sp., Campanian, Hokkaido, diameter 1.3 m, D. Aiba (Mikasa) for scale. Note the symmetrical bulges in the posterior body chamber in C. D, juvenile conch of Scaphites whitfieldi, AMNH 44833, Turonian, U.S.A. E, embryonic conch of Aconeceras cf. trautscholdi, UMUT MM 29439-4, Aptian, Russia. F, embryonic conch of Hibolithes sp., GPIT Ce 1599, Callovian, Lithuania. G to J, Upper Disang Formation, Phek District, Nagaland. G, H, Limacinidae spp. I, J, Creseidae spp. 

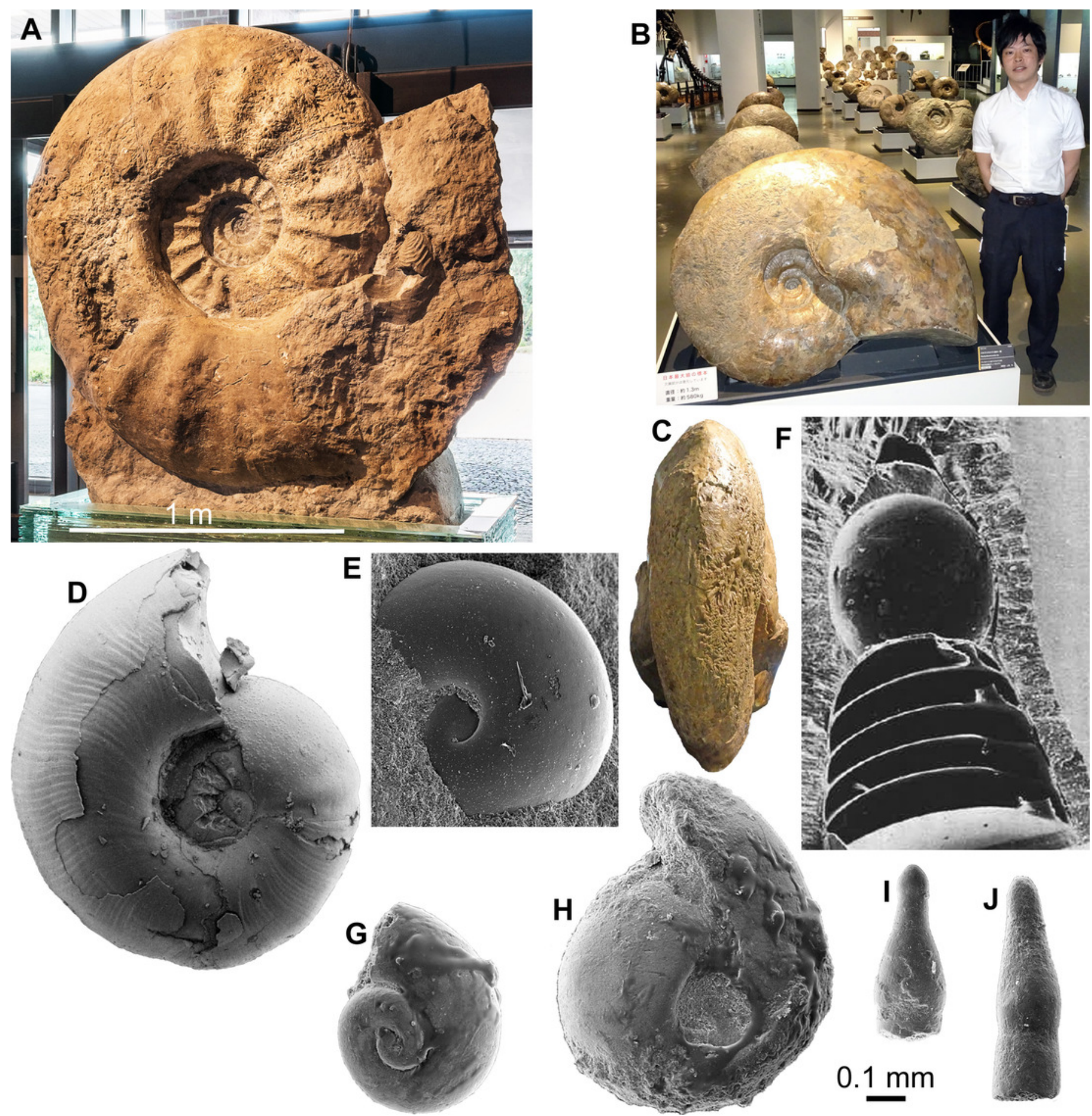


\section{Figure 2 (on next page)}

Relationship between adult conch size and the estimated number of eggs.

Data are displayed in Tab. 4. The variation seen in smaller species likely roots in differences of the embryo size. 


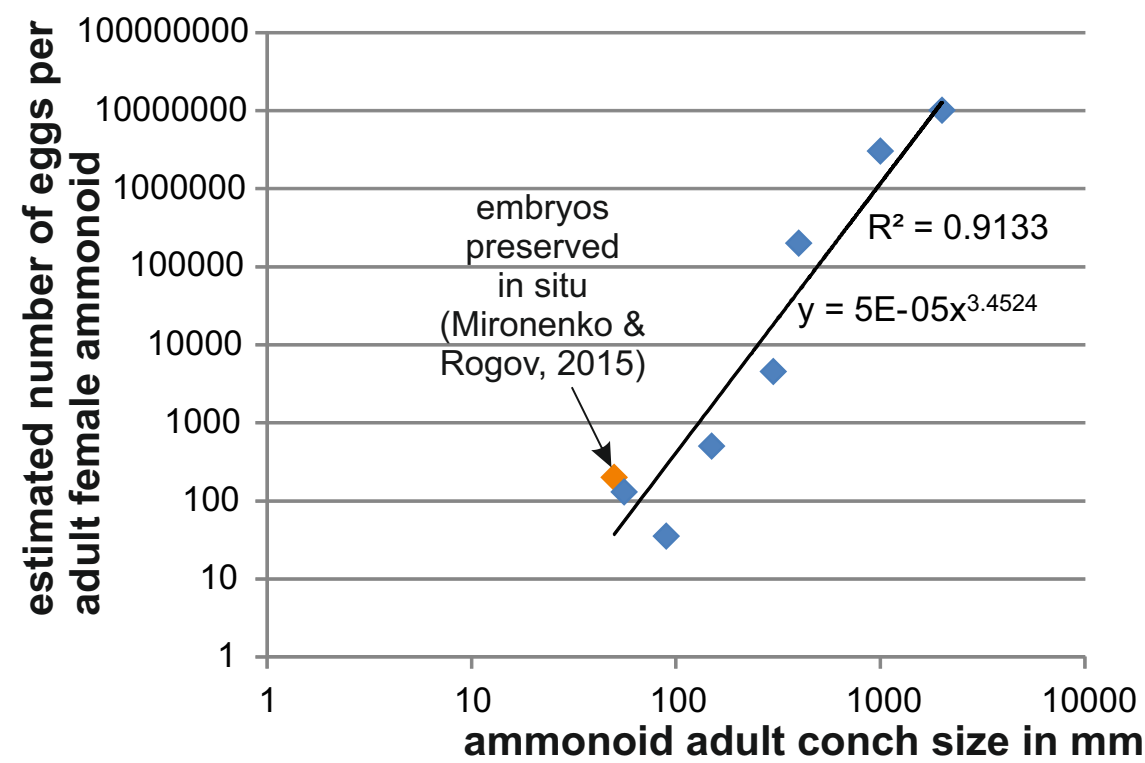


Figure 3 (on next page)

Zooplankton size ranks and filter mesh spacing of planktivorous filter feeders.

Modified after Vinther et al. (2014), using data from Lokho \& Kumar (2008), Friedman et al. (2010) and De Baets et al. (2015). The horizontal coloured lines connect the size ranges of zooplanktonic prey organisms with the mesh size of large filter-feeding marine vertebrates. The black lines mark the range in prey size organisms filtered by the respective filter feeders. Note how the size range of hatchlings of ammonites and belemnites match that of Thecosomata and, on the filter feeder-side, that of the mesh-size of the filtering organ. 


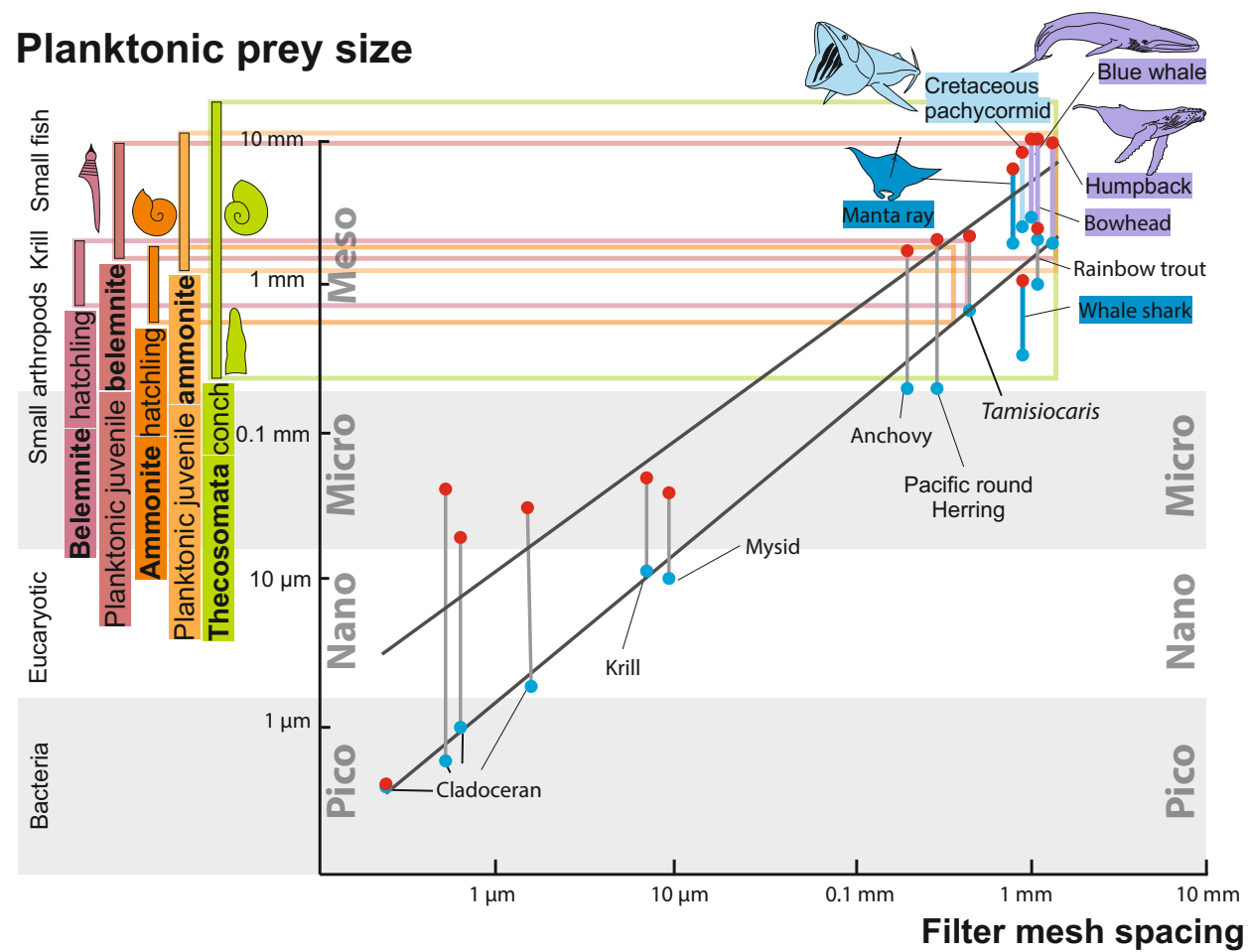


Figure 4 (on next page)

Occurrences, extinctions, originations and diversity changes in plankton and large planktotrophic suspension feeders from the Cretaceous to the Palaeogene (mass extinction marked by red bar).

Ammonite and belemnite diversity show the number of species. Data from Friedmann et al. (2010), Bristow et al. (1980), Corse et al. (2013), Yacobucci (2015) and Jarman (2001). Note relative timing of extinctions of cephalopods with small planktonic juveniles and filter feeding bony fish and rediations of holoplanktonic gastropods, krill as well as filter-feeding chondrichthyans and whales. 

large planktivorous vertebrates

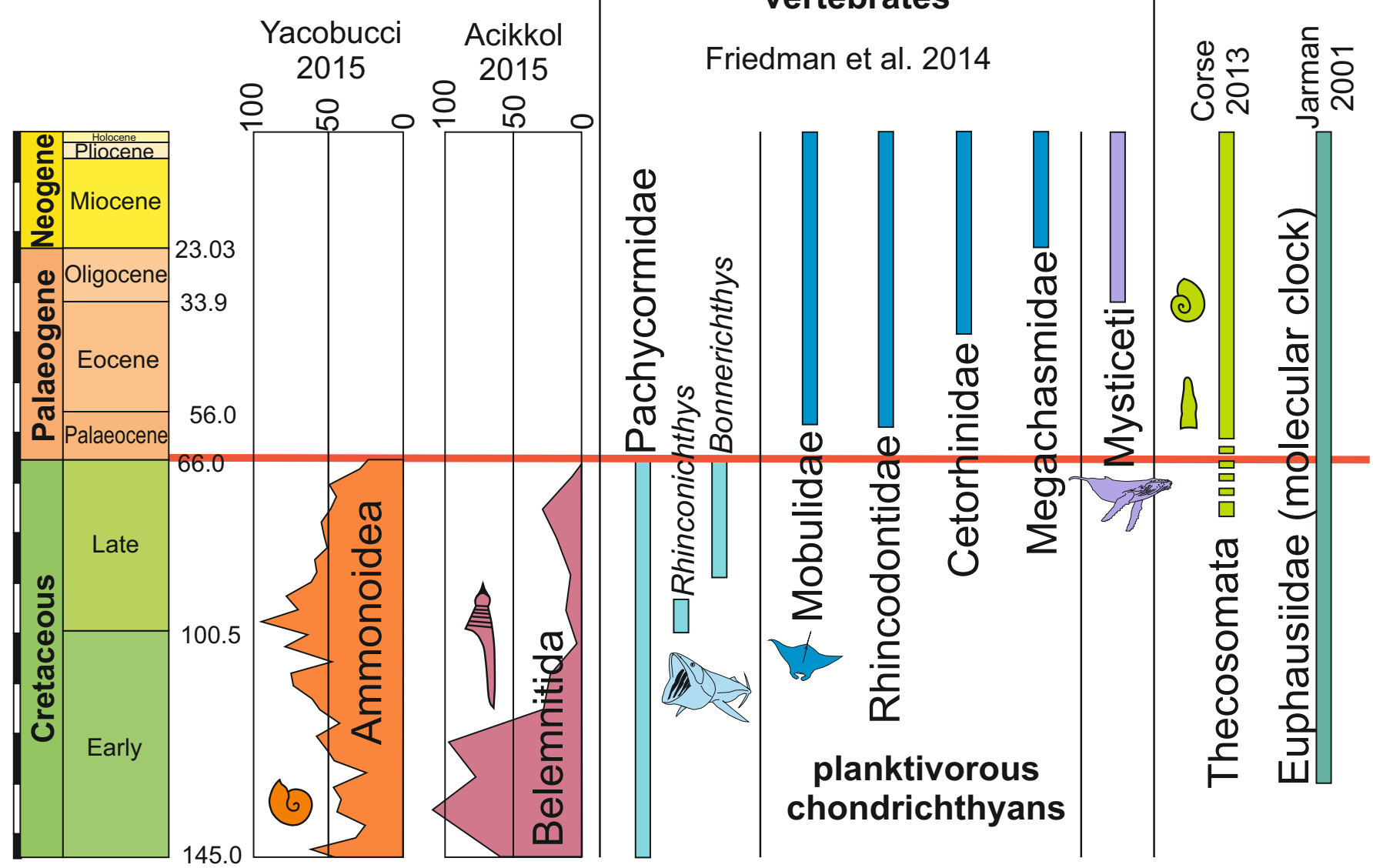


Figure $\mathbf{5}$ (on next page)

Diversity of Cephalopoda and Gastropoda through the Phanerozoic.

Redrawn after Sepkoski (1981). Note the diversity reduction in cephalopods at the end of the Cretaceous and the subsequent radiation of gastropods. The Cretaceous Palaeogene mass extinction is marked by the red line. 


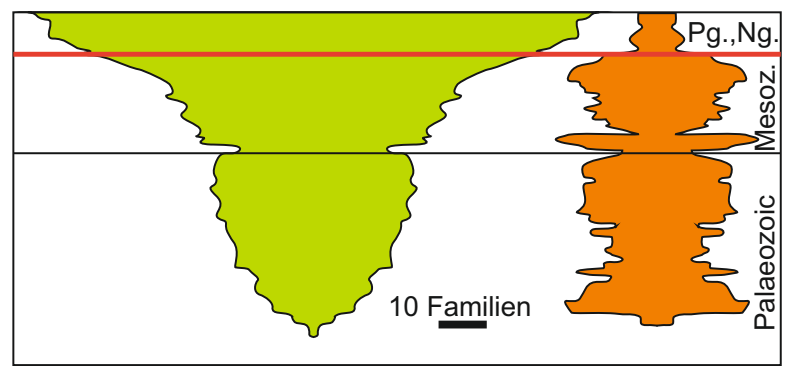

Gastropoda Cephalopoda 


\section{Figure 6 (on next page)}

Box plots of Cretaceous ammonitella diameters and Cretaceous to Palaeogene Thecosomata conch size.

Data (Tab. 1) from De Baets et al. (2015), Laptikhovsky et al. (2017), Lokho \& Kumar (2008), Janssen et al. (2007, 2016), Janssen \& Goedert (2016), and Janssen \& Peijnenburg (2017). The red line marks the Cretaceous-Palaeogene boundary. The numbers below the box plots give the sample size. Orange marks ammonitella data, while green marks gastropod data. Question marks indicate that fossils are present but the values indicate guesses: In the case of Valanginian ammonites, protoconchs are known and from that size, an ammonitella size close to $1 \mathrm{~mm}$ appears likely. In the case of Campanian and late Palaeocene Thecosomata, the only genus ranging back into the Campanian is Heliconoides (Janssen \& Goedert, 2016; Janssen \& Peijnenburg, 2017); Eocene specimens measure approximately $2 \mathrm{~mm}$, hence this size estimate. 


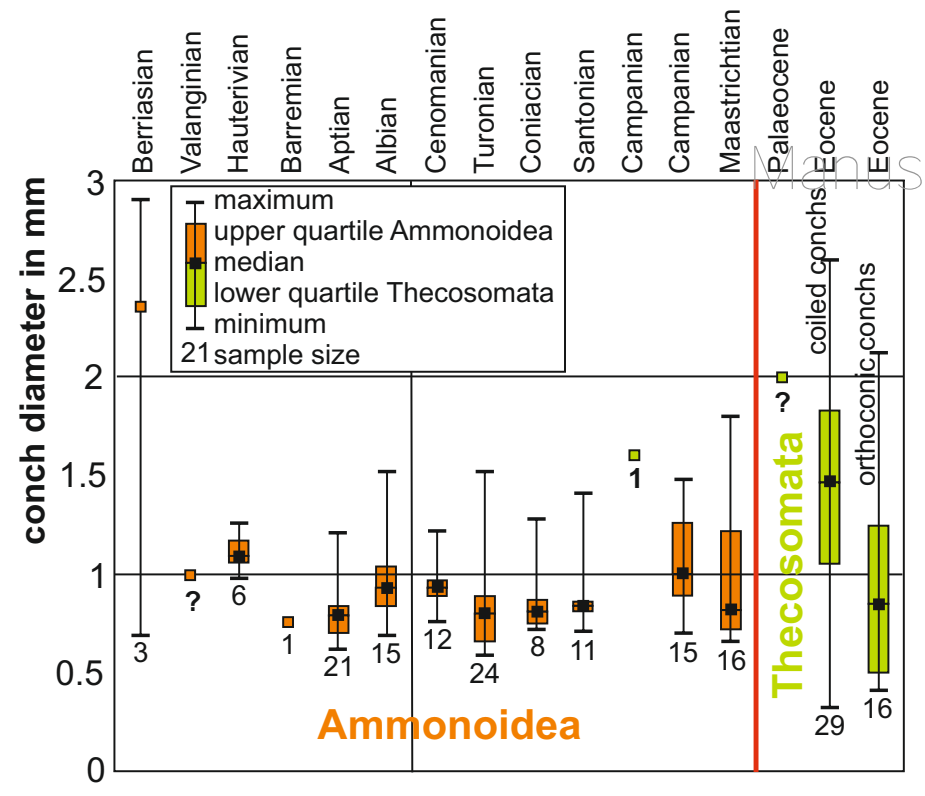




\section{Table 1 (on next page)}

Measurements of embryonic conchs of Cretaceous ammonites.

Data from De Baets et al. (2015) and Laptikhovsky et al. (2017). 
1 Table 1 Measurements of embryonic conchs of Cretaceous ammonites. Data from De Baets

2 et al. (2015) and Laptikhovsky et al. (2017).

\begin{tabular}{|c|c|c|}
\hline Species & Stage & AD mean \\
\hline Acanthoplites sp. & Albian & 0.75 \\
\hline Aconeceras (Sanmartinoceras) sp. & Aptian & 0.84 \\
\hline Aconeceras trautscholdi & Aptian & 0.63 \\
\hline Aconeceras trautscholdi & Aptian & 0.77 \\
\hline Anagaudryceras limatum & Coniacian & 1.28 \\
\hline Anagaudryceras matsumotoi & Maastrichtian & 1.32 \\
\hline Anagaudryceras nanum & Campanian & 1.26 \\
\hline Anagaudryceras tetragonum & Maastrichtian & 1.26 \\
\hline Anagaudryceras yokoyamai & Santonian & 1.41 \\
\hline Baculites sp. & Santonian & 0.78 \\
\hline Beudanticeras beudanti & Albian & 1.06 \\
\hline Beudanticeras laevigatum & Albian & 0.88 \\
\hline Boreophylloceras densicostatum & Berriasian & 2.37 \\
\hline Boreophylloceras praeinfundibulum & Berriasian & 2.9 \\
\hline Calliphylloceras subalpinum & Albian & 0.8 \\
\hline Calliphylloceras velledae & Aptian & 0.84 \\
\hline Calycoceras orientale & Cenomanian & 0.93 \\
\hline Canadoceras kossmati & Campanian & 0.89 \\
\hline Canadoceras mystricum & Campanian & 1 \\
\hline Clioscaphites vermiformis & Santonian & 0.71 \\
\hline Collignoniceras woollgari & Turonian & 0.82 \\
\hline Colombiceras sp. & Aptian & 0.62 \\
\hline Damesites ainuanus & Turonian & 0.7 \\
\hline Damesites damesi & Santonian & 0.89 \\
\hline Damesites latidorsatus & Santonian & 0.85 \\
\hline Damesites semicostatus & Santonian & 0.84 \\
\hline Damesites sugata & Santonian & 0.83 \\
\hline Deshayesites deshayesi & Albian & 1 \\
\hline Desmoceras dawsoni & Albian & 1.52 \\
\hline Desmoceras ezoanum & Cenomanian & 1.22 \\
\hline Desmoceras japonicum & Turonian & 0.97 \\
\hline Desmoceras kossmati & Cenomanian & 0.85 \\
\hline Desmoceras kossmati & Cenomanian & 0.9 \\
\hline Desmoceras poronaicum & Albian & 0.84 \\
\hline Desmophyllites diphylloides & Santonian & 0.86 \\
\hline Desmophyllites diphylloides & Santonian & 0.81 \\
\hline Desmophyllites sp. & Santonian & 0.84 \\
\hline
\end{tabular}




\begin{tabular}{|c|c|c|}
\hline Desmophyllites sp. & Santonian & 0.89 \\
\hline Diadochoceras nodosocostatiforme & Aptian & 0.77 \\
\hline Diadochoceras sinuosocostatus & Aptian & 0.74 \\
\hline Diadochoceras sp. & Aptian & 0.75 \\
\hline Discoscaphites conradi & Maastrichtian & 0.76 \\
\hline Discoscaphites gulosus & Maastrichtian & 0.72 \\
\hline Discoscaphites rossi & Maastrichtian & 0.69 \\
\hline Eogaudryceras (Eotetragonites) aurarium & Albian & 0.93 \\
\hline Eogaudryceras (Eotetragonites) balmensis & Albian & 0.98 \\
\hline Eogunnarites unicus & Cenomanian & 0.76 \\
\hline Eupachydiscus haradai & Campanian & 0.9 \\
\hline Gabbioceras angulatum & Aptian & 0.88 \\
\hline Gabbioceras latericarinatum & Albian & 0.93 \\
\hline Gabbioceras michelianum & Albian & 0.9 \\
\hline Gaudryceras cf. denseplicatum & Turonian & 1.34 \\
\hline Gaudryceras cf. tenuiliratum & Campanian & 1.4 \\
\hline Gaudryceras denseplicatum & Turonian & 1.52 \\
\hline Gaudryceras stefaninii & Cenomanian & 0.93 \\
\hline Gaudryceras striatum & Campanian & 1.26 \\
\hline Gaudryceras tombetsense & Maastrichtian & 1.42 \\
\hline Hauericeras angustum & Campanian & 0.7 \\
\hline Hauericeras gardeni & Campanian & 0.72 \\
\hline Holcophylloceras guettardi & Aptian & 0.81 \\
\hline Holcophylloceras sp. & Aptian & 0.81 \\
\hline Hoploscaphites comprimus & Maastrichtian & 0.66 \\
\hline Hoploscaphites nebrascensis & Maastrichtian & 0.68 \\
\hline Hoploscaphites nicolletii & Maastrichtian & 0.77 \\
\hline Hoploscaphites spedeni & Maastrichtian & 0.76 \\
\hline Hypacanthohoplites sp. & Aptian & 0.84 \\
\hline Hypacanthohoplites subcornuenianus & Aptian & 0.93 \\
\hline Hypophylloceras hetonaiensis & Maastrichtian & 0.9 \\
\hline Hypophylloceras ramosum & Maastrichtian & 1.02 \\
\hline Hypophylloceras subramosum & Santonian & 1.03 \\
\hline Karsteniceras obatai & Barremian & 0.75 \\
\hline Kossmatella agassiziana & Albian & 1.11 \\
\hline Luppovia sp. & Aptian & 0.7 \\
\hline Mantelliceras japonicum & Cenomanian & 0.89 \\
\hline Marshallites compressus & Cenomanian & 0.97 \\
\hline Melchiorites sp. & Albian & 0.69 \\
\hline Menuites pusilus & Maastrichtian & 0.87 \\
\hline Menuites yezoensis & Maastrichtian & 0.76 \\
\hline
\end{tabular}




\begin{tabular}{|c|c|c|}
\hline Metaplacenticas subtilistriatum & Campanian & 1.14 \\
\hline Microdesmoceras tetragonum & Cenomanian & 0.94 \\
\hline Nolaniceras sp. & Aptian & 0.79 \\
\hline Parahoplites melchioris & Aptian & 1.21 \\
\hline Parajaubertella kawakitana & Cenomanian & 1.12 \\
\hline Phylloceras japonicum & Cenomanian & 0.92 \\
\hline Phyllopachyceras ezoense & Santonian & 1.08 \\
\hline Phyllopachyceras ezoense & Campanian & 0.91 \\
\hline Phyllopachyceras sp. & Aptian & 0.76 \\
\hline Protexanites minimus & Santonian & 0.74 \\
\hline Pseudohaploceras nipponicus & Aptian & 0.79 \\
\hline Pseudophyllites indra & Campanian & 1.48 \\
\hline Ptychoceras renngarteni & Aptian & 0.85 \\
\hline Ptychophylloceras ptychoicum & Berriasian & 0.69 \\
\hline Pusozia takahashii & Turonian & 0.89 \\
\hline Puzosia orientale & Turonian & 0.83 \\
\hline Puzosia pacifica & Turonian & 0.84 \\
\hline Puzosia yubarensis & Turonian & 0.61 \\
\hline Saghalinites teshioensis & Campanian & 1.19 \\
\hline Scaphites carlilensis & Turonian & 0.6 \\
\hline Scaphites corvensis & Turonian & 0.67 \\
\hline Scaphites depressus & Coniacian & 0.76 \\
\hline Scaphites larvaeformis & Turonian & 0.59 \\
\hline Scaphites nigricollensis & Turonian & 0.68 \\
\hline Scaphites planus & Turonian & 0.84 \\
\hline Scaphites preventitricosus & Turonian & 0.65 \\
\hline Scaphites pseudoaequalis & Coniacian & 0.72 \\
\hline Scaphites warreni & Turonian & 0.66 \\
\hline Scaphites whitfieldi & Turonian & 0.65 \\
\hline Scaphites yonekurai & Coniacian & 0.87 \\
\hline Simbirskites coronatiformis & Hauterivian & 1.09 \\
\hline Simbirskites discofalcatus & Hauterivian & 1.17 \\
\hline Simbirskites elatus & Hauterivian & 1.06 \\
\hline Simbirskites sp. & Hauterivian & 1.26 \\
\hline Simbirskites sp. & Hauterivian & 0.98 \\
\hline Simbirskites versicolor & Hauterivian & 1.09 \\
\hline Subprionocyclus bakeri & Turonian & 0.75 \\
\hline Subprionocyclus minimum & Turonian & 0.74 \\
\hline Subprionocyclus neptuni & Turonian & 0.78 \\
\hline Teshioites sp. & Campanian & 0.92 \\
\hline Tetragonites duvalianus & Albian & 1.06 \\
\hline
\end{tabular}




\begin{tabular}{|l|l|l|}
\hline Tetragonites glabrus & Turonian & 1.08 \\
\hline Tetragonites hulensis & Albian & 1.04 \\
\hline Tetragonites minimus & Turonian & 0.98 \\
\hline Tetragonites popetensis & Campanian & 0.97 \\
\hline Tetragonites popetensis & Campanian & 1.08 \\
\hline Tetragonites terminus & Maastrichtian & 1.8 \\
\hline Texanites kawasakii & Santonian & 0.93 \\
\hline Tragodesmoceroides subcostatus & Turonian & 0.88 \\
\hline Valdedorsella akuschaensis & Aptian & 0.68 \\
\hline Yezoites klamathensis & Coniacian & 0.75 \\
\hline Yezoites matsumotoi & Coniacian & 0.8 \\
\hline Yezoites puerculus & Coniacian & 0.82 \\
\hline Yokoyamaoceras ishikawai & Turonian & 0.89 \\
\hline Zelandites aff. inflatus & Cenomanian & 1.22 \\
\hline Zelandites kawanoii & Santonian & 1.19 \\
\hline Zelandites mihoensis & Coniacian & 1 \\
\hline Zelandites varuna & Aptian & 0.75 \\
\hline Zuercherella falcistriata & 1.22 \\
\hline
\end{tabular}

3

4 
Table 2 (on next page)

Size of conchs of Thecosomata with coiled conchs.

Data sources are indicated in the table. 
1 Table 2. Size of conchs of Thecosomata with coiled conchs. Data sources are indicated in the

2 table.

\begin{tabular}{|c|c|c|c|}
\hline Taxon & age & diameter & source \\
\hline Limacinidae & Eocene & 1.125 & Lokho \& Kumar, 2007 \\
\hline Limacinidae & Eocene & 1.05 & Lokho \& Kumar, 2007 \\
\hline Limacinidae & Eocene & 0.733333 & Lokho \& Kumar, 2007 \\
\hline Limacinidae & Eocene & 0.75 & Lokho \& Kumar, 2007 \\
\hline Limacinidae & Eocene & 0.32 & Lokho \& Kumar, 2007 \\
\hline Limacinidae & Eocene & 0.568182 & Lokho \& Kumar, 2007 \\
\hline Limacinidae & Eocene & 0.857143 & Lokho \& Kumar, 2007 \\
\hline Altaspiratella elongatoidea & Eocene & 1.416667 & Janssen et al., 2016 \\
\hline Altaspiratella elongatoidea & Eocene & 1.833333 & Janssen et al., 2016 \\
\hline Altaspiratella elongatoidea & Eocene & 1.233333 & Janssen et al., 2016 \\
\hline Heliconoides mercinensis & Eocene & 1.764706 & Janssen et al., 2016 \\
\hline Limacina aegis & Eocene & 1.4375 & Janssen et al., 2016 \\
\hline Limacina aegis & Eocene & 1.71875 & Janssen et al., 2016 \\
\hline Limacina aegis & Eocene & 1.03125 & Janssen et al., 2016 \\
\hline Limacina aegis & Eocene & 1.53125 & Janssen et al., 2016 \\
\hline Limacina aegis & Eocene & 1.84375 & Janssen et al., 2016 \\
\hline Limacina aegis & Eocene & 1.28125 & Janssen et al., 2016 \\
\hline Limacina novacaesarea & Eocene & 1.382353 & Janssen et al., 2016 \\
\hline Limacina novacaesarea & Eocene & 1.588235 & Janssen et al., 2016 \\
\hline Limacina novacaesarea & Eocene & 1.470588 & Janssen et al., 2016 \\
\hline Heliconoides lillebaeltensis & Eocene & 2.4 & Janssen et al., 2007 \\
\hline Heliconoides lillebaeltensis & Eocene & 2.5 & Janssen et al., 2007 \\
\hline Heliconoides lillebaeltensis & Eocene & 2.5 & Janssen et al., 2007 \\
\hline Heliconoides lillebaeltensis & Eocene & 2 & Janssen et al., 2007 \\
\hline Heliconoides lillebaeltensis & Eocene & 1.7 & Janssen et al., 2007 \\
\hline Heliconoides lillebaeltensis & Eocene & 1.8 & Janssen et al., 2007 \\
\hline Heliconoides mercinensis & Eocene & 2 & Janssen et al., 2007 \\
\hline Heliconoides mercinensis & Eocene & 2.6 & Janssen et al., 2007 \\
\hline Limacina pygmaea & Eocene & 1.4 & Janssen et al., 2007 \\
\hline Heliconoides sp. & Campanian & 1.56 & Janssen \& Goedert, 2013 \\
\hline Heliconoides mercinensis & Pleistocene & 2 & guess \\
\hline
\end{tabular}

3

4 


\section{Table 3 (on next page)}

Size of conchs of Thecosomata with straight conchs.

Data sources are indicated in the table. 
1 Table 3. Size of conchs of Thecosomata with straight conchs. Data sources are indicated in

2 the table.

\begin{tabular}{|l|l|l|l|}
\hline Family & age & diameter & source \\
\hline Creseidae & Eocene & 1.875 & Lokho \& Kumar, 2007 \\
\hline Creseidae & Eocene & 1.25 & Lokho \& Kumar, 2007 \\
\hline Creseidae & Eocene & 1.25 & Lokho \& Kumar, 2007 \\
\hline Creseidae & Eocene & 0.75 & Lokho \& Kumar, 2007 \\
\hline Creseidae & Eocene & 2.142857 & Lokho \& Kumar, 2007 \\
\hline Creseidae & Eocene & 0.416667 & Lokho \& Kumar, 2007 \\
\hline Creseidae & Eocene & 0.597826 & Lokho \& Kumar, 2007 \\
\hline Creseidae & Eocene & 0.597826 & Lokho \& Kumar, 2007 \\
\hline Creseidae & Eocene & 0.480769 & Lokho \& Kumar, 2007 \\
\hline Creseidae & Eocene & 0.477273 & Lokho \& Kumar, 2007 \\
\hline Creseidae & Eocene & 0.575 & Lokho \& Kumar, 2007 \\
\hline Creseidae & Eocene & 0.5 & Lokho \& Kumar, 2007 \\
\hline Cliidae & Eocene & 1.857143 & Lokho \& Kumar, 2007 \\
\hline Cliidae & Eocene & 1.145833 & Lokho \& Kumar, 2007 \\
\hline Cliidae & Eocene & 0.9375 & Lokho \& Kumar, 2007 \\
\hline Cliidae & 1.5625 & Lokho \& Kumar, 2007 \\
\hline & & & \\
\hline & & & \\
\hline & & & \\
\hline
\end{tabular}

3 
Table 4 (on next page)

Estimates of numbers of eggs produced by various ammonoid taxa. 
1 Table 4. Estimates of numbers of eggs produced by various ammonoid taxa.

\begin{tabular}{|l|l|l|l|l|}
\hline Genus & age & adult & fecundity & source \\
\hline Parapuzosia & Cretaceous & 2000 & 10000000 & this paper \\
\hline Pachydesmoceras & Cretaceous & 1000 & 3000000 & this paper \\
\hline Sinzovia & Jurassic & 50 & 200 & Mironenko \& Rogov, 2015 \\
\hline Manticoceras & Devonian & 400 & 200000 & De Baets et al., 2012 \\
\hline Erbenoceras & Devonian & 150 & 500 & De Baets et al., 2012 \\
\hline Mimosphinctes & Devonian & 90 & 35 & De Baets et al., 2012 \\
\hline Gyroceratites & Devonian & 56 & 130 & De Baets et al., 2012 \\
\hline Agoniatites & Devonian & 300 & 4500 & De Baets et al., 2012 \\
\hline
\end{tabular}

2

3 